\title{
Downscaling regional climate model estimates of daily precipitation, temperature and solar radiation data
}

\author{
M. Rivington ${ }^{1, *}$, D. Miller ${ }^{1}$, K. B. Matthews ${ }^{1}$, G. Russell ${ }^{2}$, G. Bellocchi ${ }^{3}$, K. Buchan ${ }^{1}$ \\ ${ }^{1}$ Macaulay Institute, Craigiebuckler, Aberdeen AB15 8QH, UK \\ ${ }^{2}$ School of Geosciences, Crew Building, The University of Edinburgh, West Mains Road, Edinburgh EH9 3JN, UK \\ ${ }^{3}$ Agrichiana Farming, Montepulciano, Siena, Italy
}

\begin{abstract}
The smallest spatial scale of representation by regional climate models (RCMs) - i.e. $50 \times 50 \mathrm{~km}$-is greater than that at which site-specific studies on climate change impacts, mitigation and adaptation studies are conducted. An approach is therefore needed to evaluate the quality of data from RCMs used for these purposes, to identify systematic errors and adjust future projected estimates accordingly. The present study uses a simple downscaling approach for recalibrating RCM estimates of precipitation, maximum and minimum air temperature (Tmax and Tmin), and solar radiation. We compared the Hadley Centre HadRM3 RCM-hindcast estimates for 1960 to 1990 with observed data from 15 meteorological stations in the UK. Downscaling factors (DFs) were applied to improve the match between hindcast and observed data. The DFs were then applied to the RCM data for the A2 2070 to 2100 scenario, assuming that the systematic deviations present in the hindcast estimates will persist. The hindcast RCM data included a considerable excess of small $(<0.3 \mathrm{~mm})$ precipitation events, whilst significantly overestimating the mean annual total at some sites and underestimating it at others. Estimates of Tmax were closer than for Tmin, which the model tended to overestimate by an average of $1^{\circ} \mathrm{C}$. Estimates of lower Tmax and upper Tmin values were generally good, but the model was less effective in representing extreme warm and cold conditions. The model systematically overestimated solar radiation. Because the use of DF substantially improves the fit of hindcast estimates with observed data, their use with RCM projections should considerably increase confidence in model outputs for studies on impacts, mitigation and adaptation.
\end{abstract}

KEY WORDS: Climate change - Adaptation · RCM - Downscaling - Evaluation · Precipitation · Temperature $\cdot$ Solar radiation

Resale or republication not permitted without written consent of the publisher

\section{INTRODUCTION}

A key challenge of communicating the likely effects of climate change $(\mathrm{CC})$ to decision makers is in presenting $\mathrm{CC}$ effects in relation to spatial or organisational units that are within their experience, i.e. farms, conurbations or water catchments (Droogers \& Aerts 2005, Rivington et al. 2007). A further challenge lies in helping them to understand the various sources of uncertainty in the climate scenarios so that they have appropriate levels of confidence in those projections (Maurer \& Duffy 2005). The first challenge (above) requires the development of downscaling methods that result in regional climate model (RCM) estimates that are both appropriate in a site-specific context and to the processes of concern within CC impact studies (Zhang 2005). The second challenge requires the assessment, quantification and attribution of the various sources of uncertainty. Without this information, it is difficult to ascertain whether the additional error introduced by the change of scale is small enough to avoid invalidating the conclusions of the study in question. The degree of uncertainty introduced to site-specific studies through the use of different climate data sources can be substantial (Rivington et al. 2006). 
RCMs produce estimates for grid cells that are typically for both historical (hindcast) and future time periods on a grid-box scale in the order of $50 \times 50 \mathrm{~km}$. However, CC impact, mitigation and adaptation studies increasingly consider spatial scales with a finer resolution than this. Hindcast data from RCMs permits observed and estimated data to be compared for the locations where the observations were made. The quality of estimates and, thus, the utility of futurescenario data for particular applications, can therefore be assessed (Moberg \& Jones 2004). We assume that RCM hindcast data for a particular grid cell will be 'characteristic' of observed data from individual sites within the cell (i.e. having variables with similar temporal distribution patterns and value ranges), where the site has topographical and elevation features that are similar to the mean of the cell.

The differences between RCM estimates and observations from a particular site arise from 2 sources. The first is the difference in geographical factors (e.g. topography, elevation, distance to the sea, land cover-particularly for coastal sites and where a significant proportion of a RCM cell consists of water) between the site and the cell average. The second is related to the adequacy of the RCM in representing the climate processes that result in spatial variability.

There are obviously micro-and meso-climatic effects that an RCM cannot be expected to represent, such as frost hollows or coastal fog. It is likely, however, that there will also be systematic differences due to the RCM structure and a parameterisation intended to achieve the best fit across the whole RCM area. Since the RCM spatial-attribute representation, structure and parameterisation are common to both the hindcast and future scenarios, then downscaling factors (DFs) found by comparing observed with hindcast data may be used to downscale estimates of future climate for particular sites. This will improve the reliability of sitespecific CC studies by reducing the likelihood that the estimated CC impacts are an artefact of the differences between site characteristics and their representation within the RCM.

In the present study we compare precipitation, maximum and minimum air temperature (Tmax and Tmin), and solar radiation hindcast data produced by the Hadley Centre HadRM3 RCM with observed data for 15 locations within the UK, for the period 1960 to 1990. The aim was to develop a protocol for identifying systematic errors in RCM estimates for a range of locations, and thus develop site-specific DFs to reduce the discrepancy between observed and modelled hindcast data. The overall purpose was that the resulting DFs can then be used to adjust future estimates to correct for biases in the modelling of climate processes within the RCM-i.e. 'modelling uncertainty' (Murphy et al.
2004) - and to correct for differences between the characteristics of the RCM grid and the specific location-i.e. 'representation uncertainty'. This procedure does not deal with 'scenario uncertainty' (Jenkins \& Lowe 2003) - i.e. the estimates of future greenhouse gas (GHG) emissions, and depends on the availability of appropriate hindcast data for any GHG scenario.

\section{RELATED RESEARCH}

\subsection{Background}

CC data from RCMs are increasingly being made available to the wider research community. Much of the testing of such data has been conducted with the aim of improving the predictive performance of the models themselves (e.g. Peng et al. 2002, Antic et al. 2006), with rather less testing of the utility of estimates as part of particular impact assessments. Examples of the latter type of study include Bell et al. (2004), who compared a model with observed data as part of a larger study of growing season length and temperature and precipitation extremes in California. Studies that have compared estimates with observed data tend to focus on individual weather variables at regional scales (e.g. Achberger et al. 2003), though some consider site-specific data, e.g. Fowler et al. 2005, who tested HadRM3H RCM for extreme rainfall events at 204 sites in the UK. Moberg \& Jones (2004) tested the HadRM3P model estimates of daily nearsurface Tmax and Tmin for the period 1961 to 1990 for 185 meteorological stations across Europe. Their analysis was primarily based on the model-minusobserved values for mean annual and seasonal temperature differences, though results for daily differences (forming the annual temperature cycle) were given for 6 locations. They found large spatial variations in the ability of the model to reproduce historical weather effectively. It performed well in the UK and some other locations between 50 and $55^{\circ} \mathrm{N}$, with differences generally being $\pm 0.5^{\circ} \mathrm{C}$, but other regions showed differences of up to $\pm 15^{\circ} \mathrm{C}$. Whilst this study provided valuable information about the degree of spatial variability in the accuracy of temperature estimates, it was insufficiently detailed to show the spatial pattern of daily differences. For a single site (Florence, Italy) Moriondo \& Bindi (2006) concluded that the HadCM3 Global Circulation Model (GCM) and HadRM3P RCM were not able to recreate the Tmax and Tmin patterns for most of the year, with both (particularly the GCM) failing to make projections that were close to the seasonal means. Differences have not only been found for temperature and precipitation. Kim \& Lee (2003) found that surface insolation 
was generally overestimated in an 8 yr hindcast simulation for the Western United States, with differences smaller over land than over sea.

Whilst examples exist of downscaling from global to regional scales (e.g. Widmann et al. 2003), and of statistical methods from regional to local scales (e.g. Wilby et al. 2002, Maurer \& Duffy 2005), there is little evidence in the literature of non-statistical based methods for regional to specific sites. Exceptions include the method developed by Ines \& Hansen (2006) to interpolate the frequency and intensity distribution of daily precipitation from a GCM to a specific site in Kenya. Similarly Zhang (2005) downscaled monthly GCM precipitation and temperature data using transfer functions for one site in Oklahoma, USA. Kleinn et al. (2005) used correction factors to adjust RCM precipitation and temperature data used within a model chain for assessing stream flows within the catchment of the River Rhine. Similarly, Hay et al. (2002) in applying magnitude-based bias corrections to the RegCM2 model-found that estimates improved the overall output from a basin scale hydrological model, but corrected data did not contain sufficient daily variability to match observed weather data. Wood et al. (2004) conducted a detailed assessment of simple statistical downscaling methods (linear interpolation; spatial disaggregation; bias-correction and spatial disaggregation) applied to a Parallel Climate Model (PCM) and an RCM, but compared to a gridded climatology of precipitation and temperature. The bias-correction and spatial disaggregation approach gave the best results when the adjusted climate estimates were used within a hydrological model.

\subsection{Data used in impact studies}

Part of the rationale for this paper is to better understand how biases in RCM estimates will affect $\mathrm{CC}$ impact studies. A primary approach in investigating and communicating the effects of $\mathrm{CC}$ is through the use of simulation models. It is therefore essential to understand how uncertainties introduced to such models will manifest themselves when estimated climate data is used as input. The uncertainty introduced into biophysical systems models due to the input weather data can be significant (Rivington et al. 2006). For example, Nonhebel (1994a) showed that the use of mean monthly instead of daily data in a crop simulation model resulted in an overestimation of potential production by 5 to $15 \%$, and up to $50 \%$ in water-limited production in dry conditions. Nonhebel (1994b) found that inaccuracies in solar radiation of $10 \%$ and of daily temperature of $1^{\circ} \mathrm{C}$ resulted in errors in grain yield estimates of up to $1 \mathrm{t}$ $\mathrm{ha}^{-1}$, and up to $10 \mathrm{~d}$ difference in the duration of the vegetative period (crop emergence to flowering) in cereals.

Maintaining meteorologically appropriate, correlated relationships between individual weather variables is essential for models that represent entities with non-linear responses to the driving variables often encountered within biological systems (Nonhebel 1994a) and hydro-chemical processes (Soulsby 1995). Thermal-time accumulation, which depends on the difference between daily Tmax and Tmin, is the key driver of plant and insect phenological development. Systematic errors in the estimation of values of either Tmax or Tmin and their temporal synchronisation will result in predictions of either faster (earlier) or slower (later) development, with corresponding impacts on associated management (i.e. crop) or behavioural (i.e. plant-insect-predator) responses.

When using climate projections to formulate adaptation and mitigation strategies, the uncertainties in RCM estimates, and the lack of quantification of the effect of these uncertainties on CC studies, hinders evidence-based decision making. Introduced systematic biases may lead to erroneous decisions being made and inappropriate actions being taken. Hindcast RCM data provide a unique opportunity to assess the nature of the uncertainty that would be introduced into systems models' predictions by the use of RCM rather than site specific information. Whilst the daily data from GCM and RCM can only be indicative of future conditions, with potentially large changes in data resulting from small changes in model structure or parameters, impact studies will, nevertheless, use such data. By identifying any systematic biases and minimising them for particular locations through the use of downscaling methods, the robustness of any decisions based on RCM estimates for future climates will be significantly improved.

\section{MATERIALS AND METHODS}

\subsection{Data sources}

The British Atmospheric Data Centre (http://badc. nerc.ac.uk/home/index.html) provided observed daily precipitation $(\mathrm{mm}), \operatorname{Tmax}$ and $\operatorname{Tmin}\left({ }^{\circ} \mathrm{C}\right)$ and total downward surface shortwave flux (direct and diffuse solar radiation, $\mathrm{SR}, \mathrm{MJ} \mathrm{m}^{2} \mathrm{~d}^{-1}$ ) data for 1960 to 1990 for 15 meteorological stations in the UK (Fig. 1). Observed data were compiled within an Oracle database, where errors, duplicates and anomalies in the original data were identified and corrected. Missing observed values were filled using a search and optimisation method (LADSS 2005). 


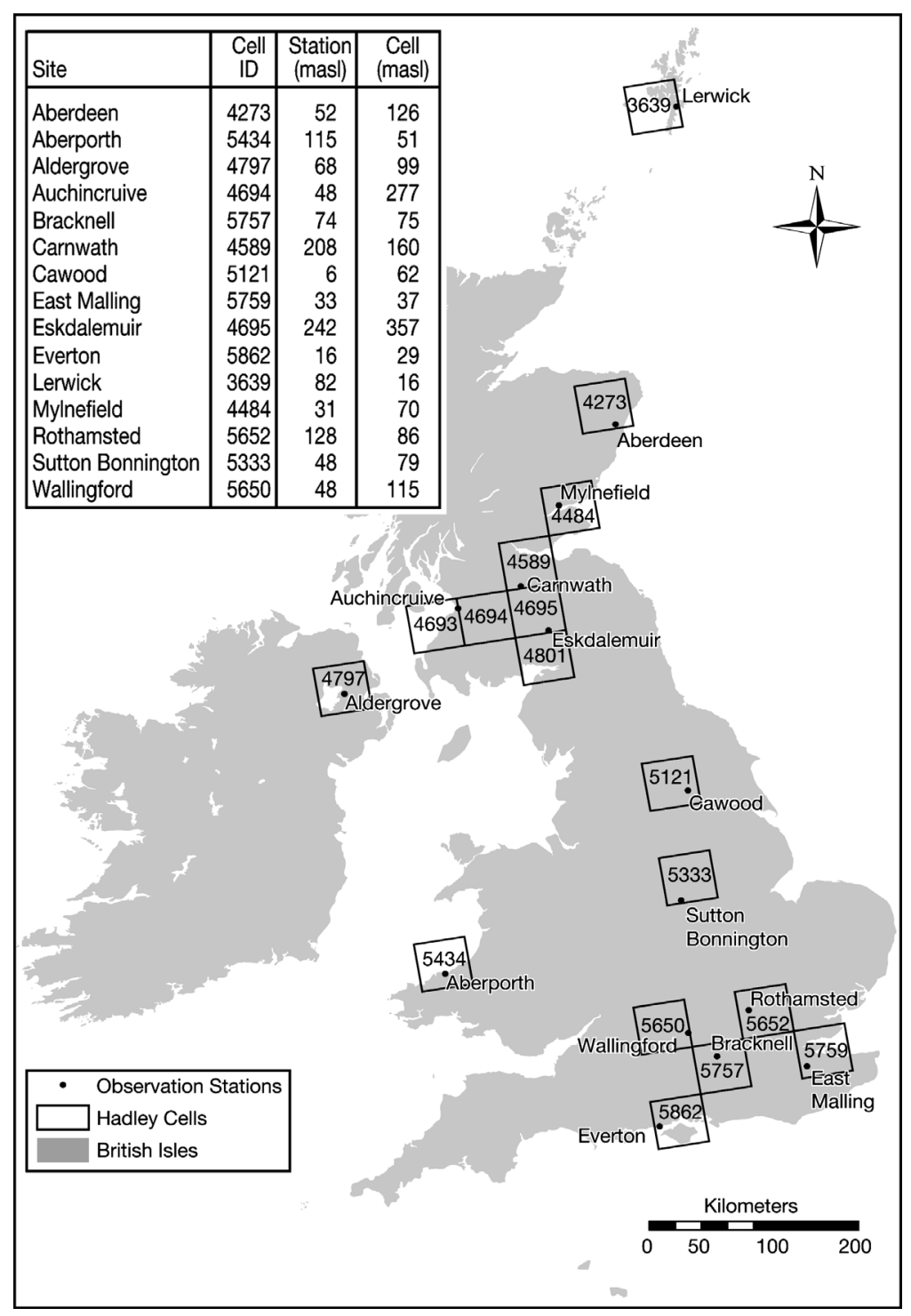

Fig. 1. Meteorological stations in the UK providing observed data, the associated HadRM3 $50 \times 50 \mathrm{~km}$ grid cells, and station and mean cell elevations (mean above sea level, $\mathrm{m}$ a.s.l.)

Modelled data originates from the Hadley Centre HadRM3 RCM archive for $50 \times 50 \mathrm{~km}$ grid cells (the extent of each RCM cell used is shown in Fig. 1). As an initial condition ensemble, 5 hindcast simulations (starting from 1860) were produced by the HadRM3 in order to establish 1960 to 1990 climate-normal period 'baselines' to be used for comparisons with future projections. Each hindcast simulation had slight variations in their initialisation conditions, but atmospheric $\mathrm{CO}_{2}$ and other GHG concentrations were varied to match the historical concentrations up until 1990. Future projections of GHGs, as per the Special Report on Emissions Scenarios (SRES) (IPCC 2000) were not applied until after 1990. The present study used the
SRES A2 (medium-high GHG emissions) initial realisation hindcast (based on observed historical GHG concentrations). As such, this paper assesses only one example of the hindcast configurations of the HadRM3.

A meteorological station was matched with its corresponding cell. Selection criteria for sites with observed data were the completeness of their data record, and their location in relation to an idealised uniform spatial distribution across the UK. The number of sites available for assessment was limited by the availability of SR data. Carnwath in southwest Scotland, despite not having SR data, was included as it is a site of on-going CC impacts modelling. In 2 cases, stations were within $2 \mathrm{~km}$ of the cell boundary (Auchincruive and Eskdalemuir), so the opportunity was taken to use the closest neighbouring RCM cells for comparison as well.

The hindcast data produced by the RCM do not attempt to recreate synoptic conditions for specific locations or years. Instead they aim to provide a time series of data with the correct statistical properties, including correlations between variables. The RCM outputs represent the $50 \times 50 \mathrm{~km}$ grid cell as a whole, rather than any specific site within the cell, and are time(year-) independent. Therefore direct day-to-day or year-with-year comparisons between the observed and RCM data are not possible. Instead, mean daily, annual totals or maximum and minimum values were used for comparisons. As the HadRM3 model treats a year as having $360 \mathrm{~d}$ (i.e. $12 \mathrm{mo}$ of $30 \mathrm{~d}$ ), the last $5 \mathrm{~d}$ of the observed data for each year were omitted from the analyses, though this risks the exclusion of significant extreme weather events in this time period.

Based on the findings of Moberg \& Jones (2004), no a priori adjustments to the modelled data were made to take account of differences in elevation or other climatologically significant topographic differences between the meteorological station and the mean for the grid cell. The mean elevation for each grid cell and meteorological station is given in Fig. 1.

This study consisted of 4 stages: (1) assessment of the quality of the hindcast estimates against observed data; (2) development of DFs; (3) re-assessment of downscaled hindcasts against observed data; and (4) application of DFs to future projections. 


\subsection{Data quality assessment}

The first stage of the work compared modelled and observed data for the period 1960 to 1990 for each weather variable at the 15 locations (17 cells).

3.2.1. Precipitation. Histograms were plotted to illustrate the frequency distribution of the magnitude of precipitation events $(>0 \mathrm{~mm})$. For each precipitation event the probability of excedence $(P e)(\%)$ was calculated following Weibull (1961):

$$
P e=m /(\mathrm{n}+1) \times 100
$$

where $m$ is the rank order of each precipitation event, with $m=1$ as the largest event and $m=n$ for the lowest, with $\mathrm{n}$ being the number of observations (in this case $\mathrm{n}=$ $360 \mathrm{~d} \times 30 \mathrm{yr}$ ). Where precipitation amounts are equal, they have the same $m$ value. This method enables differences in the probability of occurrence of precipitation events of the same magnitude to be identified and avoids the problem of asynchronicity in the timing of precipitation. As such the method does not take into account the day of year that each data value represents (i.e. observed and modelled data of the same Pe may have occurred on different days). Using the ranked decreasing order of precipitation event, the difference (modelled - observed) and proportional difference, compared with the observed event magnitude [(modelled - observed) / observed] was calculated. The mean annual precipitation, magnitude of largest event and the mean number of days with no precipitation (dry days) were calculated. To assess the temporal distribution of events, plots of the $7 \mathrm{~d}$ (weekly) means were made.

3.2.2. Temperature. The mean daily values for Tmax and Tmin were calculated and plotted for the observed and estimated data. This enabled the magnitude of differences and their temporal distribution within a year to be visually assessed. The root mean square error (RMSE) and 2-tailed paired Student's $t$-test of the probability of equal means (p) were estimated for comparison of observed and hindcast mean daily, and highest and lowest values, of Tmax and Tmin for a set of example locations. Mean daily Tmax - Tmin was calculated and plotted, in order to assess the model's ability to represent the daily temperature range. The highest and lowest daily values of Tmax and Tmin were plotted to examine how well the model was able to represent daily variability and extreme ranges. The mean annual Tmax and Tmin and highest and lowest temperatures were calculated, along with the mean number of days when temperature exceeded 3 thresholds: Tmax $>15^{\circ} \mathrm{C}$, Tmin $<0^{\circ} \mathrm{C}$ and $\operatorname{Tmin}<-5^{\circ} \mathrm{C}$.

3.2.3. Solar radiation. Observed SR data records are often incomplete for the 1960-1990 period; hence, analysis was limited to graphical representations using the difference between mean daily observed and esti- mated solar radiation. This difference in daily means helps to illustrate the temporal distribution of mean daily errors (over- and underestimations) over the period of a year, indicating systematic model behaviour. This approach was taken to allow direct comparison of results with a previous study of the performance of 3 solar radiation models carried out by Rivington et al. (2005). Observed and modelled SR data were also smoothed by calculating a $7 \mathrm{~d}$ running mean (mean of Days 1 to 7 , mean of Days 2 to 8 etc.) and then plotted to emphasise the annual distribution pattern.

\subsection{Development of downscaling factors}

DFs were developed after completion of the data quality analysis to minimise the difference in means between the observed and RCM hindcast values for each weather variable. The DFs were applied to the daily data. For Tmax, Tmin and SR, 3 temporal intervals were tested for the application of the DF: annual (1 DF for the entire year); growing season and non-growing season (2 DFs, one for each season); and monthly (1 DF for each month). Further tests applied the DF by multiplication and addition. Initial investigation showed that the annual time period and the multiplication application methods were unsatisfactory. The seasonal time period (2 DFs) improved the match between modelled and observed data, but contained unrealistic 'steps' at the day of change between seasons. The following details the best method, i.e. the application of monthly values of DF by addition (where the DF can be positive or negative) to Tmax, Tmin and SR.

3.3.1. Precipitation. Precipitation DFs were handled differently from the other weather variables in that a 2-stage approach was used. Firstly, a single value $\left(\mathrm{DF}_{\mathrm{d}}\right)$ was subtracted from the value of every event to correct the number of days with no precipitation $(0 \mathrm{~mm})$ and reduce the difference in distribution of low precipitation events seen in Fig. 2. The value of $\mathrm{DF}_{d}$ was found by the implementation of an iterative loop, whereby an optimal value was found to subtract from each event value such that it minimises the mean number of observed - estimated dry days difference. If the event value $-\mathrm{DF}_{\mathrm{d}}$ became $<0$, then the value was set to 0 . Hence $D F_{d}$ is effectively a single optimal value of a precipitation event amount below which all data values $>0 \leq \mathrm{DF}_{\mathrm{d}}$ can be removed. A significant number of very small (generally $<0.3 \mathrm{~mm}$ ) modelled precipitation events are removed, which then requires the application of a second DF ( $\mathrm{DF}_{\mathrm{MAT}}$; mean annual total) to correct for both the model's original error in estimating mean annual total (MAT) and the new reduced value.

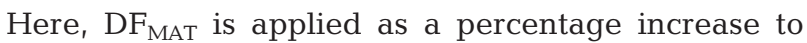
non-zero values, where the increase is proportional to 

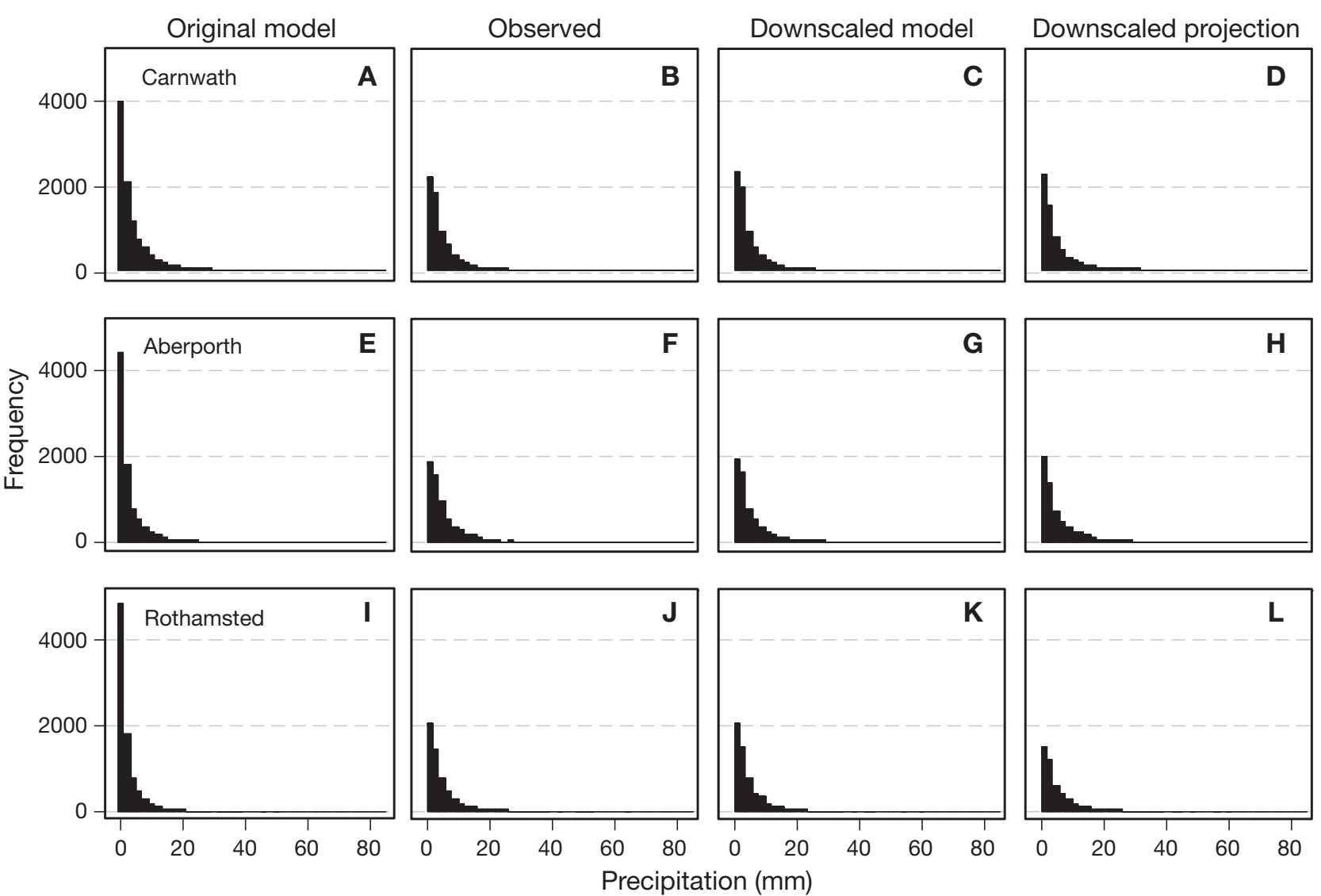

Precipitation (mm)

Fig. 2. Observed and modelled precipitation at 3 selected sites: (A-D) Carnwath, (E-H) Aberporth, and (I-L) Rothamstead. $(\mathrm{A}, \mathrm{E}, \mathrm{I})$ HadRM3 modelled hindcast estimates, $(\mathrm{B}, \mathrm{F}, \mathrm{J})$ observed data, and $(\mathrm{C}, \mathrm{G}, \mathrm{K})$ downscaled HadRM3 hindcast estimates (1960-1990). (D,H,L) Downscaled HadRM3 A2 scenario projection (2070-2100)

the size of the modelled value, i.e. value + (value $\times$ $\left.\mathrm{DF}_{\mathrm{MAT}}\right)$. The objective for $\mathrm{DF}_{\mathrm{MAT}}$ was to minimise the difference $\left(D_{\mathrm{MAT}}\right)$ between the mean of the observed annual totals $\left(O_{\mathrm{MAT}}\right)$ and the estimated MATs $\left(E_{\mathrm{MAT}}\right)$, where $\left(D_{\text {MAT }}\right)$ was found by:

$$
D_{\mathrm{MAT}}=\overline{\sum_{i=1}^{\mathrm{n}} O_{\mathrm{MAT}}}-\overline{\sum_{i=1}^{\mathrm{n}} E_{\mathrm{MAT}}}
$$

Precipitation DFs do not take into account seasonality, as the distribution of the excessive number of small events was even throughout the year, and the DF $\mathrm{MAT}_{\mathrm{M}}$ values are applied proportionally to the magnitude of each event.

3.3.2. Air temperature and solar radiation. DFs $\left(\mathrm{DF}_{\text {Tmax }}, \mathrm{DF}_{\mathrm{Tmin}}\right.$ and $\left.\mathrm{DF}_{\mathrm{SR}}\right)$ were developed for Tmax, Tmin and SR, respectively, where the minimised value was the difference between the observed and modelled sum of daily means per month:

and

$$
\mathrm{DF}_{\mathrm{Tmax}}=\overline{O_{\operatorname{Tmax} j i}}-\overline{E_{\mathrm{Tmax} j i}}
$$

and

$$
\mathrm{DF}_{\mathrm{Tmin}}=\overline{O_{\mathrm{Tmin} j i}}-\overline{E_{\mathrm{Tmin} j i}}
$$

$$
\mathrm{DF}_{\mathrm{SR}}=\overline{\mathrm{O}_{\mathrm{SR} j i}}-\overline{\mathrm{E}_{\mathrm{SR} j i}}
$$

where $O_{\operatorname{Tmax} j i}$ is the observed Tmax in the year $j$ and day $i$ per month $(30 \mathrm{~d})$ and $E_{\text {Tmax } j i}$ is the modelled Tmax in the year $j$ and day $i$ per month (and the same, correspondingly, for Tmin and SR). Hence 12 individual DF were developed for each weather variable for each month for all years (i.e. one $\mathrm{DF}_{\text {Tmax }}$ applied to hindcast January 1960 to 1990 data, one for February, etc.).

\subsection{Application of downscaling factors to future estimates}

On the assumption that uncertainties in RCM estimates for the hindcast period are systematic, and therefore exist in future projections, DF were applied to projected future CC data. The same assessments made of the hindcast estimates were repeated for the future projections. Plots were made for each weather variable at each location for observed and the downscaled A2 future projection. 


\section{RESULTS}

\subsection{Model estimate evaluation}

Additional results material referred to here but not illustrated are available from LADSS (2006).

4.1.1. Precipitation. The model produces an excess of small $(<0.3 \mathrm{~mm})$ precipitation events (Fig. 2), resulting in a large underestimate of the number of dry days (Table 1). The mean number of dry days for all sites was 67 compared with 163 for observed data. For the MAT, the model was able to produce very good estimates at some sites (i.e. Cawood, underestimated by only $1 \mathrm{~mm}$ ), but also poor estimates (e.g. Auchincruive, Cell 4694, overestimated by $662 \mathrm{~mm}$; Eskdalemuir, Cell 4801, underestimated by $854 \mathrm{~mm}$ ), underestimating for 10 of the 17 cells assessed (Table 1). Despite overestimating the number of dry days, the model underestimated the number of rainfall events in the range of 2 to $30 \mathrm{~mm}$ (Fig. 3B). The differences between observed and modelled data for larger rainfall events are proportionally smaller and have a less significant effect on overall totals than the more frequent small to mid-range events.

Where the model overestimates the MAT, the overestimation of precipitation events increased asymptotically to a maximum of $10 \mathrm{~mm}$ at $23 \mathrm{~mm}$ and then decreased towards $0 \mathrm{~mm}$ at $50 \mathrm{~mm}$ (beyond $50 \mathrm{~mm}$ there were insufficient events to discern a consistent pattern). In contrast, where the model underestimated the MAT, there was a near-linear increase in the underestimation, to a maximum of $22 \mathrm{~mm}$ at $50 \mathrm{~mm}$. Where the model performed well, differences were due to the larger observed events.

The model underestimated the largest single precipitation event at 14 of the 17 cells (observed mean maximum event for all sites was $72 \mathrm{~mm}$ compared with a modelled mean of $58 \mathrm{~mm}$ ). However, only at Mylnefield did the model overestimate by $>10 \mathrm{~mm}$ (Table 1 ). The largest single observed event was at Aberdeen $(109.2 \mathrm{~mm})$ where the model estimated $50 \mathrm{~mm}$. The largest modelled event was $73 \mathrm{~mm}$. The patterns of mean weekly precipitation (Fig. 4) were replicated well, e.g. Carnwath, Rothamsted, Sutton Bonington.

4.1.2. Temperature. The model estimates Tmax well for some times in the year, particularly the spring period (e.g. Auchincruive, Cell 4693, Fig. 5), but overestimates Tmin (e.g. Carnwath and Rothamsted, Fig. 6, and East Malling, see Fig. 10A), although this was not true of all sites. This resulted in a daily range (Tmax Tmin, Fig. 7) that was too narrow, particularly in the spring and summer. The main discrepancies in Tmax are underestimates in the autumn and overestimates in mid-summer (i.e. Everton, Fig. 6) and at the beginning of the year (i.e. Carnwath, Fig. 6). At Aldergrove, how-

Table 1. Comparison between observed and HadRM3 hindcast (1960-1990) precipitation (mm) for mean annual total, maximum (largest) single event and mean number of days (n) per year without precipitation (dry days, $0 \mathrm{~mm}$ ), for before and after application of downscaling factors and downscaled A2 HadRM3 scenario projections (2070-2100). Obs: observed; Model: HadRM3 hindcast; Diff: difference (before or after downscaling-observed); $\uparrow$ increase; $\downarrow$ decrease; $\approx$ approximately the same

\begin{tabular}{|c|c|c|c|c|c|c|c|c|c|c|c|c|c|c|c|}
\hline \multirow[t]{2}{*}{ Stn } & \multirow[t]{2}{*}{ Cell } & \multicolumn{6}{|c|}{$\longrightarrow$ Mean annual total $(\mathrm{mm})$} & \multicolumn{4}{|c|}{ Maximum single event (mm) } & \multicolumn{4}{|c|}{ Dry days $(0 \mathrm{~mm})$} \\
\hline & & OBS & $\begin{array}{r}\text { Bef } \\
\text { Model }\end{array}$ & $\begin{array}{l}\text { fore } \\
\text { Diff }\end{array}$ & $\begin{array}{r}\text { Aft } \\
\text { Model }\end{array}$ & $\begin{array}{l}\text { ter } \\
\text { Diff }\end{array}$ & $\begin{array}{c}\text { Downscaled } \\
\text { Projection }\end{array}$ & Obs & $\begin{array}{r}\text { Mc } \\
\text { Before }\end{array}$ & $\begin{array}{l}\text { lodel } \\
\text { e After }\end{array}$ & $\begin{array}{c}\text { Downscaled } \\
\text { Projection }\end{array}$ & Obs & $\begin{array}{r}\text { Mo } \\
\text { Before }\end{array}$ & del & $\begin{array}{c}\text { Downscaled } \\
\text { Projection }\end{array}$ \\
\hline Aberdeen & 4273 & 761 & 604 & -157 & 731 & -30 & $733 \approx$ & 109 & 50 & 67 & 79 & 173 & 57 & 167 & 195 \\
\hline Aberporth & 5434 & 870 & 838 & -31 & 858 & -12 & $921 \uparrow$ & 85 & 66 & 72 & 57 & 163 & 76 & 159 & 165 \\
\hline Aldergrove & 4797 & 845 & 814 & -31 & 833 & -12 & $818 \approx$ & 66 & 49 & 53 & 60 & 130 & 64 & 131 & 153 \\
\hline Auchincruive & 4693 & 936 & 1074 & 138 & 929 & -7 & $395 \downarrow$ & 72 & 59 & 54 & 34 & 156 & 48 & 148 & 220 \\
\hline Auchincruive & 4694 & 936 & 1597 & 662 & 928 & -8 & $1006 \uparrow$ & 72 & 73 & 47 & 47 & 152 & 47 & 147 & 159 \\
\hline Bracknell & 5757 & 663 & 761 & 98 & 658 & -5 & $626 \downarrow$ & 71 & 56 & 55 & 50 & 193 & 78 & 190 & 217 \\
\hline Carnwath & 4589 & 832 & 723 & -109 & 817 & -15 & $835 \approx$ & 59 & 64 & 75 & 74 & 135 & 63 & 133 & 159 \\
\hline Cawood & 5121 & 536 & 535 & -1 & 550 & 14 & $594 \uparrow$ & 66 & 60 & 69 & 45 & 183 & 83 & 193 & 211 \\
\hline East Malling & 5759 & 650 & 547 & -103 & 642 & -8 & $595 \downarrow$ & 82 & 63 & 81 & 66 & 193 & 95 & 190 & 220 \\
\hline Eskdalemuir & 4695 & 1534 & 1215 & -319 & 1514 & -21 & $1552 \uparrow$ & 95 & 66 & 87 & 86 & 127 & 48 & 125 & 148 \\
\hline Eskdalemuir & 4801 & 1534 & 681 & -854 & 1514 & -20 & $1580 \uparrow$ & 95 & 48 & 108 & 121 & 127 & 77 & 125 & 149 \\
\hline Everton & 5862 & 738 & 777 & 40 & 732 & -6 & $716 \downarrow$ & 56 & 55 & 58 & 56 & 203 & 63 & 201 & 224 \\
\hline Lerwick & 3639 & 1201 & 1057 & -144 & 1186 & -15 & $1279 \uparrow$ & 59 & 42 & 54 & 74 & 96 & 23 & 103 & 103 \\
\hline Mylnefield & 4484 & 692 & 500 & -192 & 659 & -33 & $665 \approx$ & 49 & 73 & 102 & 108 & 175 & 79 & 167 & 193 \\
\hline Rothamsted & 5652 & 674 & 619 & -55 & 666 & -7 & $622 \downarrow$ & 64 & 50 & 59 & 61 & 178 & 79 & 176 & 210 \\
\hline Sutton Bonnington & 5333 & 601 & 711 & 110 & 598 & -3 & $555 \downarrow$ & 59 & 50 & 48 & 62 & 191 & 70 & 189 & 215 \\
\hline Wallingford & 5650 & 577 & 693 & 116 & 574 & -3 & $549 \downarrow$ & 65 & 61 & 59 & 57 & 204 & 79 & 200 & 225 \\
\hline Mean (all sites) & & 858 & 809 & -49 & 846 & -11 & $826 \downarrow$ & 72 & 58 & 68 & 67 & 163 & 67 & 161 & 186 \\
\hline
\end{tabular}



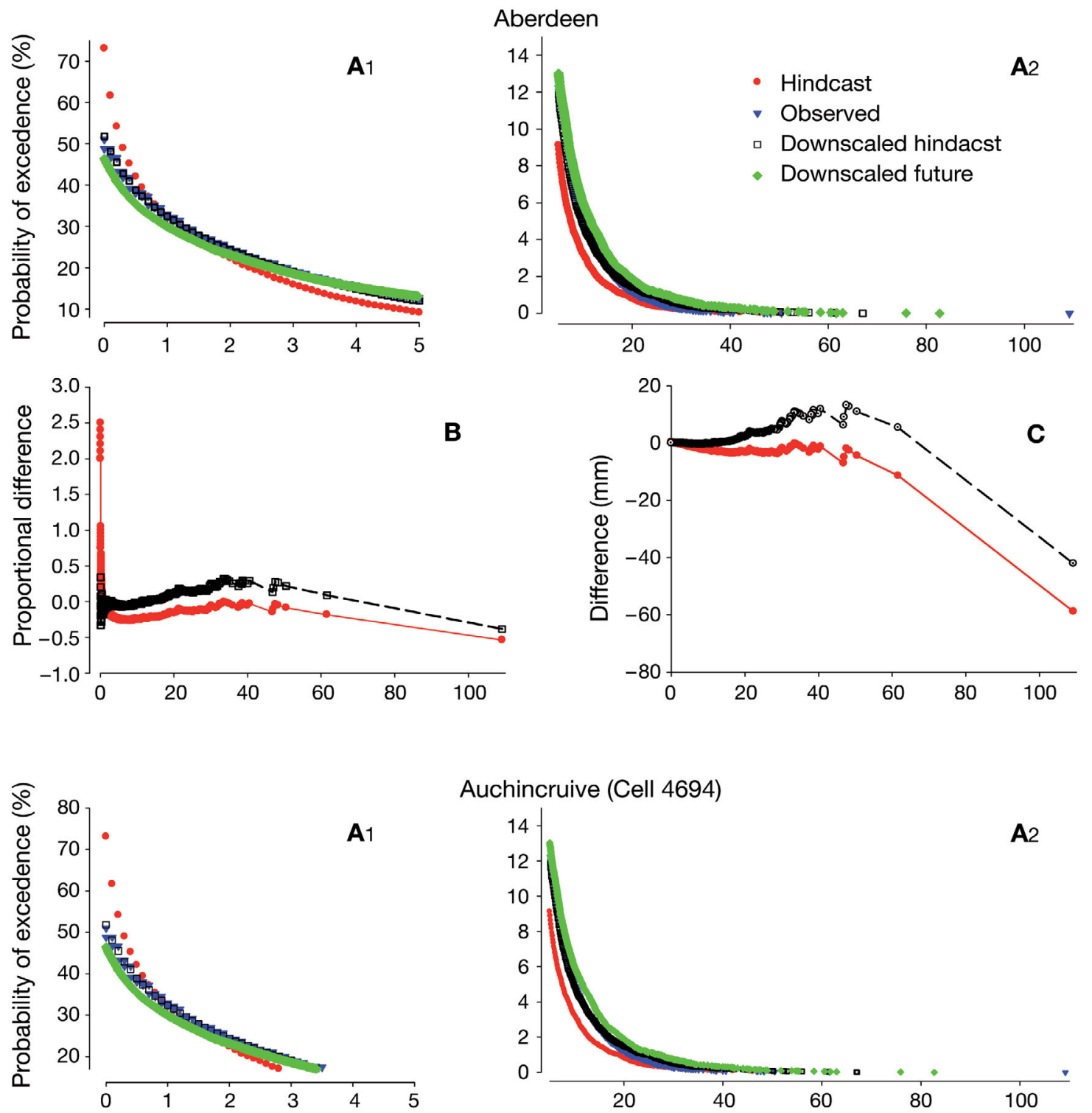

Auchincruive (Cell 4694)
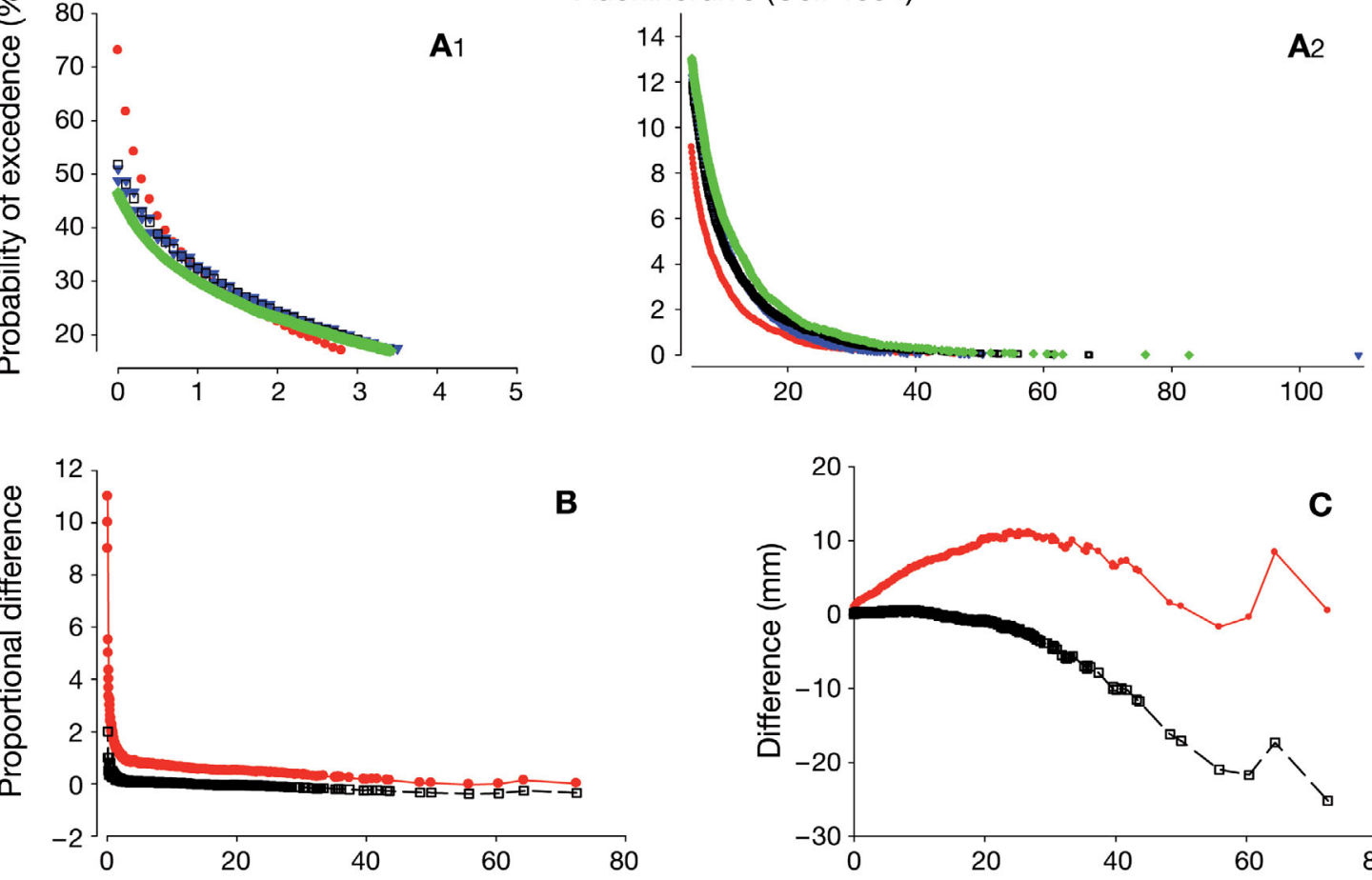

\section{Precipitation (mm)}

Fig. 3. (A1, A2) Probability of excedence plots for precipitation (A1) <5 mm and (A2) $>5 \mathrm{~mm}$ for HadRM3 hindcast, observed data downscaled HadRM3 hindcast (1960-1990) and downscaled HadRM3 A2 scenario projections (2070-2100). (B) Proportional difference plots and (C) difference plots for HadRM3 hindcast and downscaled HadRM3 hindcast. Data are presented for 4 selected sites, where Auchincruive (Cell 4694) represents the largest overestimation and Eskdalemuir (Cell 4801) represents the largest underestimation of mean annual precipitation 

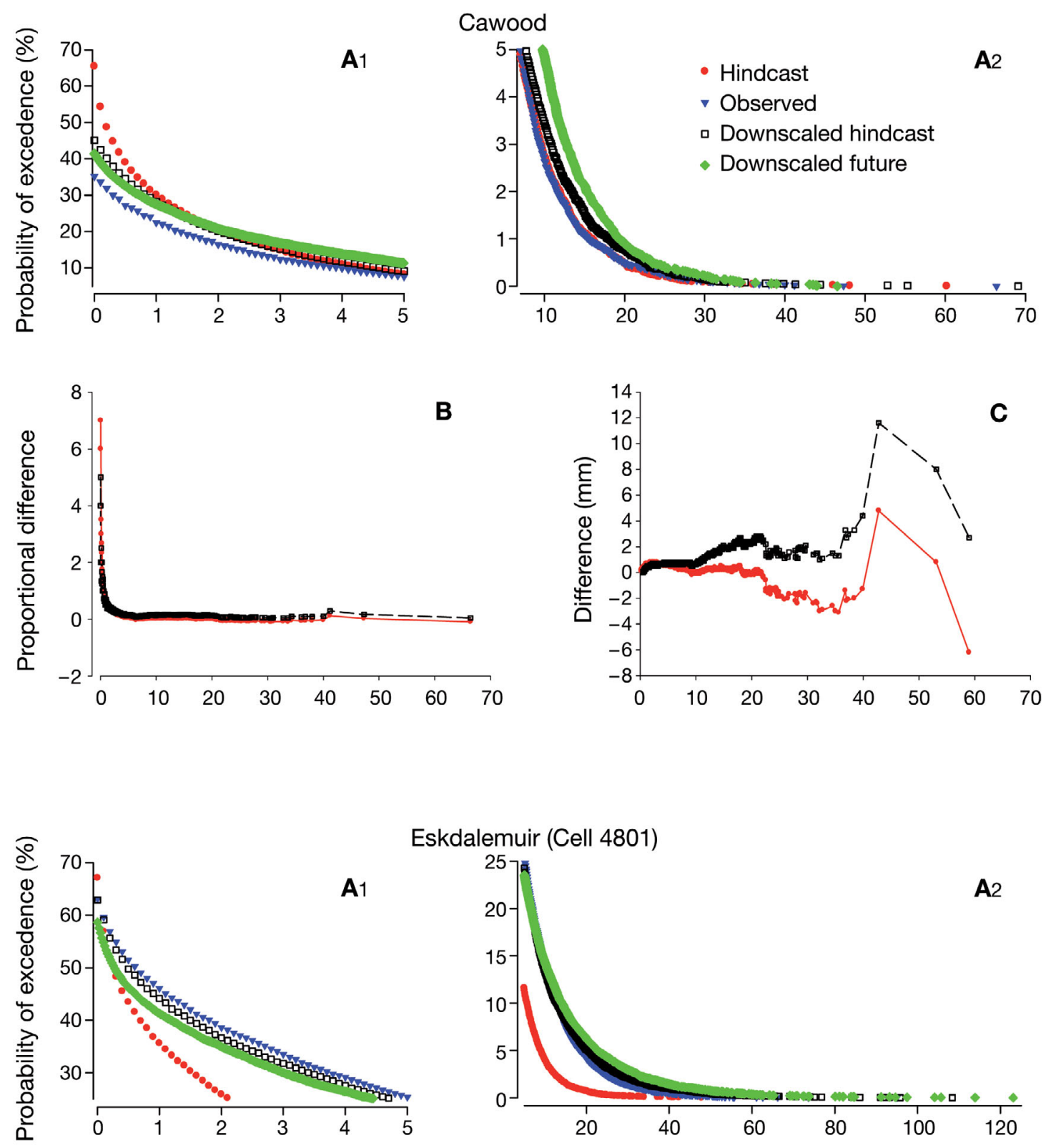

Eskdalemuir (Cell 4801)
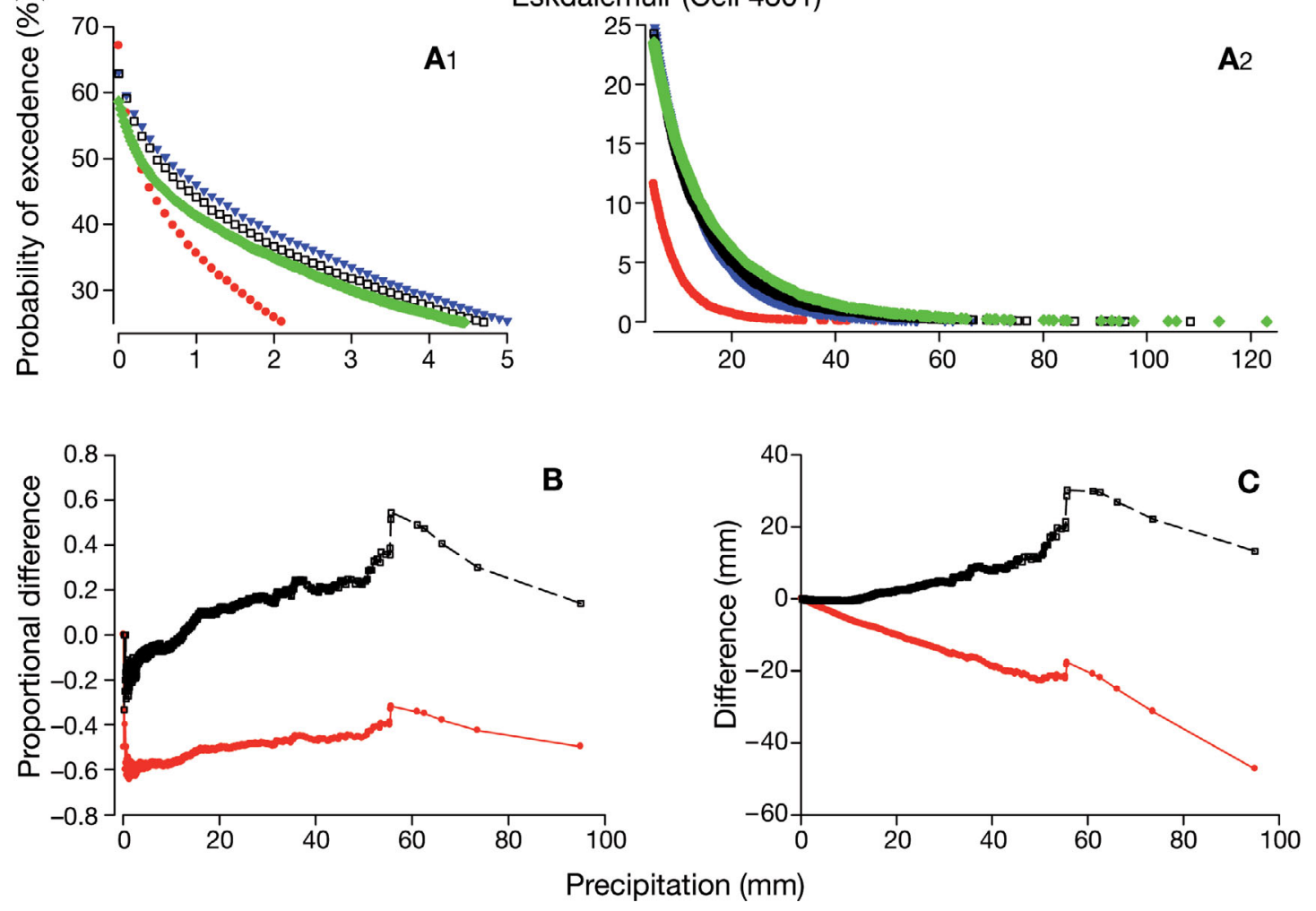

Fig. 3 (continued) 

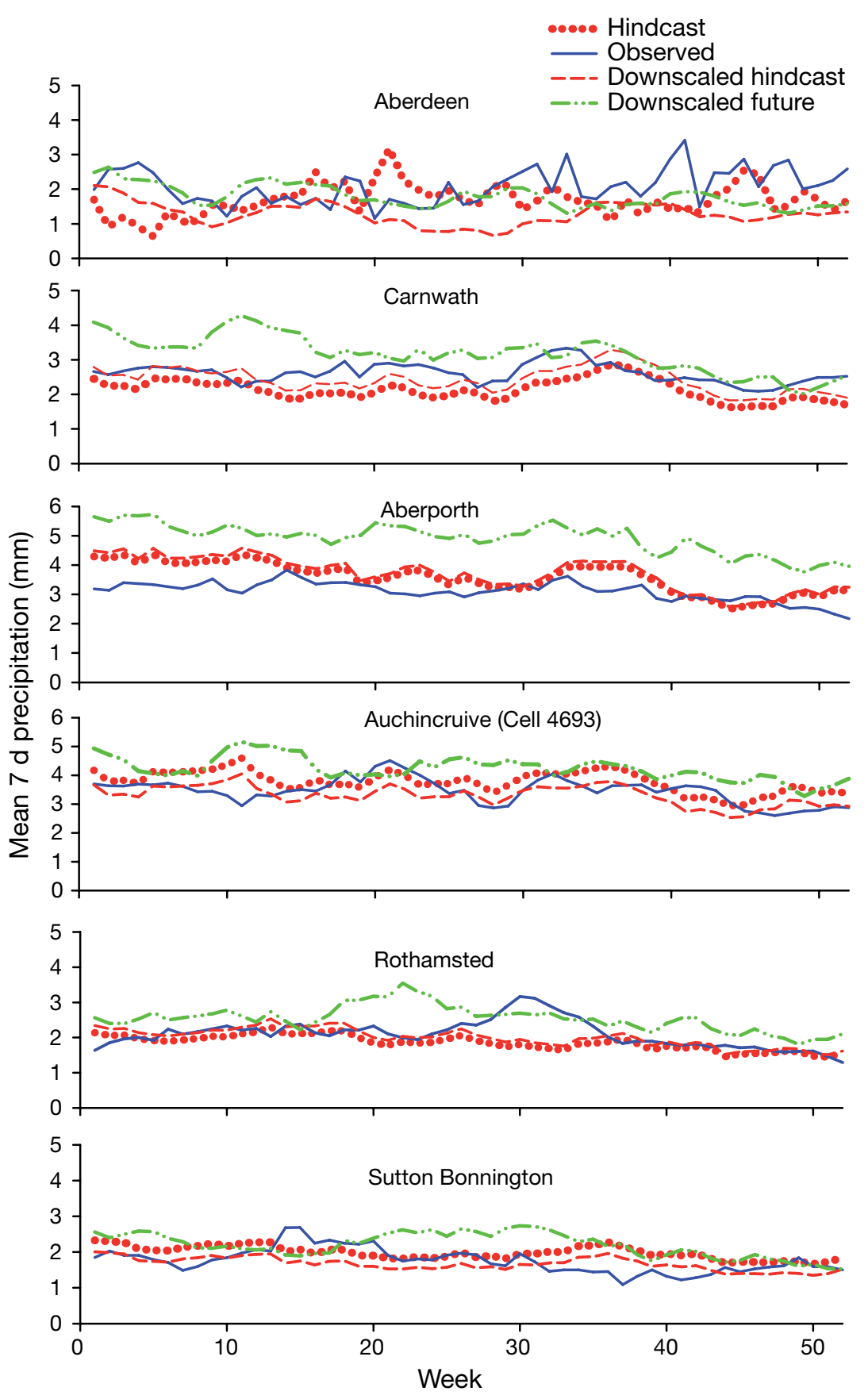

Fig. 4. Mean of $7 \mathrm{~d}$ precipitation for HadRM3 hindcast observed data, and downscaled HadRM3 hindcast (1960-1990); and downscaled A2 scenario projections (2070-2100) for selected sites

ever, the modelled Tmin matched the observed values well, but Tmax was underestimated, except in January and February.

Annual mean Tmax is generally underestimated by a small amount $\left(0.30^{\circ} \mathrm{C}\right)$, while mean Tmin is overestimated by an average of $0.72^{\circ} \mathrm{C}$. The model tends to underestimate annual mean Tmax (except at higher elevation sites) by a mean absolute difference of $0.48^{\circ} \mathrm{C}$, whilst overestimating Tmin (except at most coastal sites) by a mean absolute difference of $1.06^{\circ} \mathrm{C}$ (Table 2).

The highest Tmax values were overestimated at 14 of the 17 cells (observed mean for all sites was $30.7^{\circ} \mathrm{C}$ compared with the modelled mean of $34.2^{\circ} \mathrm{C}$ ), though at some, e.g. Aldergrove, the estimates were very close. For the lowest estimates of Tmax, the model underestimated by an average of $1.7^{\circ} \mathrm{C}$, but did not manage to replicate the lower Tmax values, i.e. at Carnwath (Table 3). It also underestimated the mean number of days when the Tmax was $>15^{\circ} \mathrm{C}$ by an average of $14 \mathrm{~d} \mathrm{yr}^{-1}$ compared with observed data, and for some locations by as much as $35 \mathrm{~d}$ (Auchincruive, Cell 4694). At Bracknell (Fig. 8A), the model overestimated the highest values of Tmax during the summer but underestimated them in the early spring, whilst there is a very good match for the lowest Tmax values.

For Tmin, the highest values were overestimated by an average of $3.6^{\circ} \mathrm{C}$, but for some locations, e.g. Rothamsted, by as much as $7.5^{\circ} \mathrm{C}$ whilst for Aberdeen it was exactly right (Table 4 ). The model did not estimate the lowest observed values of Tmin well (Fig. 8), being on average $5.9^{\circ} \mathrm{C}$ higher (warmer) than the observed values (Table 4). Generally, Tmin did not match those of the observed mean daily temperatures in the winter period. An exception (surprisingly, as it contains some area of sea within the cell) is Everton (Fig. 6), where the lowest model estimate was $3.5^{\circ} \mathrm{C}$ too low. The lowest observed Tmin value of $-24.8^{\circ} \mathrm{C}$ was at Carnwath, where the model estimated $-12.0^{\circ} \mathrm{C}$. The model underestimated the total number of days below $0^{\circ} \mathrm{C}$ in some locations and overestimated in others. Deviations ranged from $38 \mathrm{~d}$ too few (Carnwath) to $31 \mathrm{~d}$ too many (Everton). A similar pattern is seen in the estimates of days below $-5^{\circ} \mathrm{C}$, with under- and overestimates of $-19 \mathrm{~d}$ (Carnwath) and $+17 \mathrm{~d}$ (Everton).

For the highest Tmin values, the model overestimated in the summer but showed a good match throughout the rest of the year. The modelled lowest Tmin values did not effectively represent the extreme observed lows at many sites, e.g. Bracknell (Fig. 8) and 

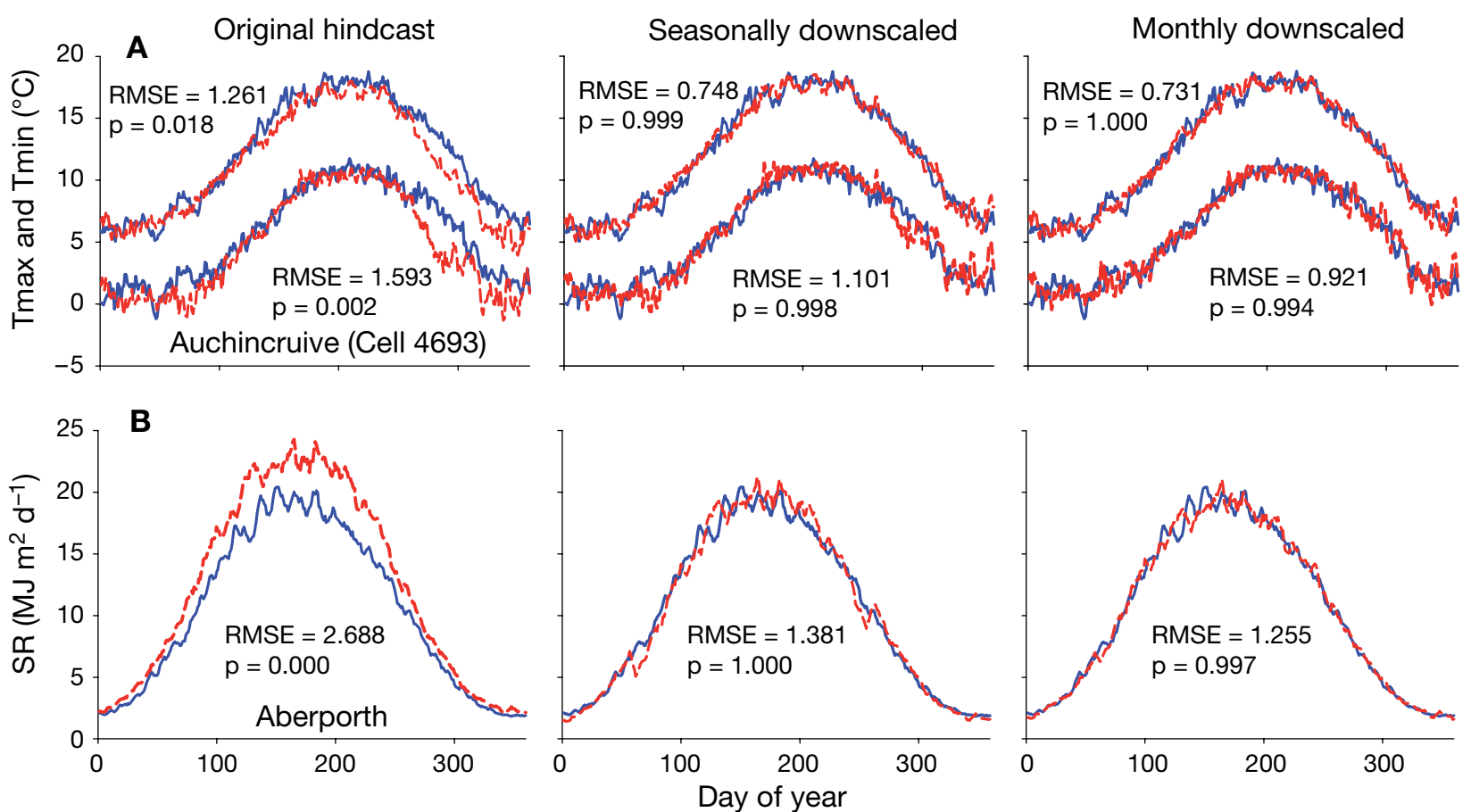

Fig. 5. Comparison of improvement in HadRM3 hindcast data (red) with observed data (blue), through application of seasonal and monthly downscaling factors for (A) mean temperature (Tmax, upper blue and red lines; Tmin, lower blue and red lines), and (B) smoothed mean daily solar radiation (SR). RMSE: root mean square error in ${ }^{\circ} \mathrm{C}$ and $\mathrm{MJ} \mathrm{m}^{2} \mathrm{~d}^{-1}$ for temperature and solar radiation, respectively; p: 2-tailed paired $t$-test probability of means being equal (where 1 is very high probability). RMSE and $\mathrm{p}$ values derived from unsmoothed data for solar radiation

the spring and summer values were generally overestimated.

Generally the temporal distribution of mean daily Tmax and Tmin is modelled adequately, based on the synchronisation of temporal distributions (see Figs. 6 \& 10A). Data from meteorological stations on the boundary between 2 cells (Auchincruive and Eskdalemuir) show contrasting results in data from their 2 corresponding modelled cells. For example, Auchincruive (Cells 4693 and 4694) showed similar temperature results (Tables 2, 3 \& 4), but a marked difference in precipitation (Table 1). Hence care has to be taken in deciding which cell data are most representative of sites on cell boundaries.

4.1.3. Solar radiation. The model systematically overestimated SR (i.e. Aberporth, Figs. 5 \& 9). It does, however, perform very well at some locations, e.g. Aberdeen, where the distribution of estimate errors is similar to that from data derived from specialist radiation estimation models. Estimates at sites such as Aberdeen were only about $\pm 1 \mathrm{MJ} \mathrm{m}^{-2} \mathrm{~d}^{-1}$ larger than those from specialist models, but are much larger at other locations, e.g. Eskdalemuir (Cell 4801), where the mean error was $2.02 \mathrm{MJ} \mathrm{m}^{-2} \mathrm{~d}^{-1}$ and the largest single error was $11.2 \mathrm{MJ} \mathrm{m}^{-2} \mathrm{~d}^{-1}$. The model overestimated SR particularly in the late summer to autumn period, when actual values are likely to be high, but there is a shift back towards either accuracy or underestimation in the spring to early summer period (e.g. East Malling, Everton, Rothamsted and Sutton Bonington, Fig. 9). This indicates a possible systematic model bias.

\subsection{Model estimate downscaling}

4.2.1. Precipitation. The $\mathrm{DF}_{\mathrm{d}}$ and $\mathrm{DF}_{\mathrm{MAT}}$ produced downscaled hindcast model data that visually match the observed data very well. The many low-magnitude (generally $<0.3 \mathrm{~mm}$ ) modelled precipitation events were removed (Figs. 2 \& 3B), resulting in better agreement in the number of dry days (Table 1), with the modelled mean for all sites being 161 (was 67) compared with the observed 163. The largest difference in the number of dry days was only 10, at Cawood. The MAT match was improved at all locations, except Cawood, where the model's original estimates were already very good (Table 1 ). $\mathrm{DF}_{\mathrm{d}}$ and $\mathrm{DF}_{\mathrm{MAT}}$ resulted in the modelled estimates of mean annual precipitation (except Cawood) being underestimated, but by a mean across all sites of only $11 \mathrm{~mm}$. At Eskdalemuir (Cell 4801) the model originally underestimated by $854 \mathrm{~mm}$, but after downscaling the difference was only $20 \mathrm{~mm}$ with an error of 2 dry days, whilst also seeing a sub- 


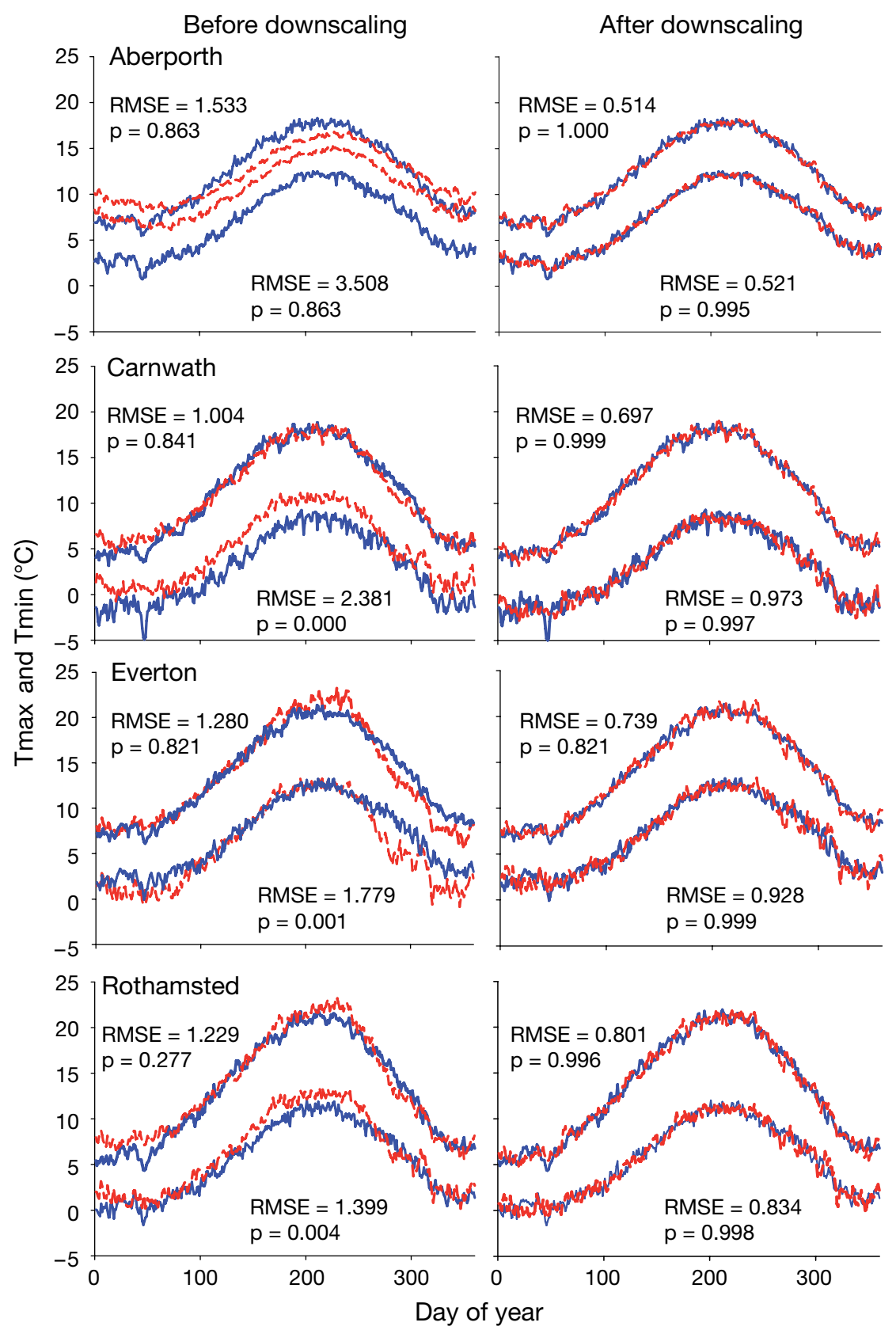

Fig. 6. Comparison of improvement in data quality of HadRM3 hindcast (red) before and after application of monthly downscaling factors of Tmax (upper red and blue lines) and Tmin (lower red and blue lines) at 4 selected sites. RMSE: root mean square error $\left({ }^{\circ} \mathrm{C}\right)$; $\mathrm{p}$ : 2-tailed paired $t$-test probability of means being equal (where 1 is very high probability) (observed $=49 \mathrm{~mm}$, hindcast $=73 \mathrm{~mm}$, downscaled projection $=102 \mathrm{~mm}$ ).

The difference (ranked observed modelled) shows that the DF maintains a closer match for the more frequent low to mid-range precipitation events (Fig. 3C), whilst minimising the proportional difference (Fig. 3B). There was a mixed response of the $7 \mathrm{~d}$ mean precipitation (Fig. 4), where the DF appear to improve the match at some locations (i.e. Rothamsted and Auchincruive, Cell 4693), but not at others (i.e. Aberporth).

4.2.2. Temperature. Application of monthly $\mathrm{DF}_{\text {Tmax }}$ and $\mathrm{DF}_{\text {Tmin }}$ resulted in substantial improvements in the match between observed and downscaled model mean daily Tmax and Tmin (Fig. 6). Most notable is the improvement in Tmin, illustrated by Carnwath, giving a better representation of daily temperature range (Tmax - Tmin) (Fig. 7), although still not ideal in the growing season. However, the downscaled data still did not represent the extreme cold events well, or reduce enough the model's overestimation of the highest values of Tmax in summer (Fig. 8B).

The estimates of annual means of Tmax and Tmin were improved at all sites (Table 2), with Tmin being seen to improve the most (the mean difference in [observed - hindcast] data for all sites was $0.3^{\circ} \mathrm{C}$ for Tmax, and $0.72^{\circ} \mathrm{C}$ for Tmin, with both becoming $0^{\circ} \mathrm{C}$ after downscaling). For Tmax, the downscaled model data still showed an overestimation of the highest single event (Table 3 ), actually worsening by $0.8^{\circ} \mathrm{C}$ from the hindcast for the mean for all sites, and multiple high events in the summer (Fig. 8B). There was an improvement in the number of ${\mathrm{d} \mathrm{yr}^{-1}}^{-1}$ estimated to be $>15^{\circ} \mathrm{C}$ (observed mean for all sites $=116$, downscaled modelled mean $=115$ ). For Tmin, there stantial improvement in the largest single event estimate (observed $=95 \mathrm{~mm}$, hindcast $=48 \mathrm{~mm}$, downscaled projection $=108 \mathrm{~mm}$ ). However, at only 9 of the 17 cells did the $\mathrm{DF}_{\mathrm{d}}$ and $\mathrm{DF}_{\mathrm{MAT}}$ improve the estimates of the largest precipitation events. The worst case for this is found at Mylnefield, where the model originally overestimated the largest precipitation amount was little change in the estimates of the lowest temperature events, but a slight improvement in the highest events (Table 4). Generally the downscaled data better represent the no. of $\mathrm{d}<0^{\circ} \mathrm{C}$, but are noticeably better for $\mathrm{d}<-5^{\circ} \mathrm{C}$ (i.e. Carnwath observed $=28 \mathrm{~d}$, original model $=9 \mathrm{~d}$, downscaled modelled data $=26 \mathrm{~d})$. 

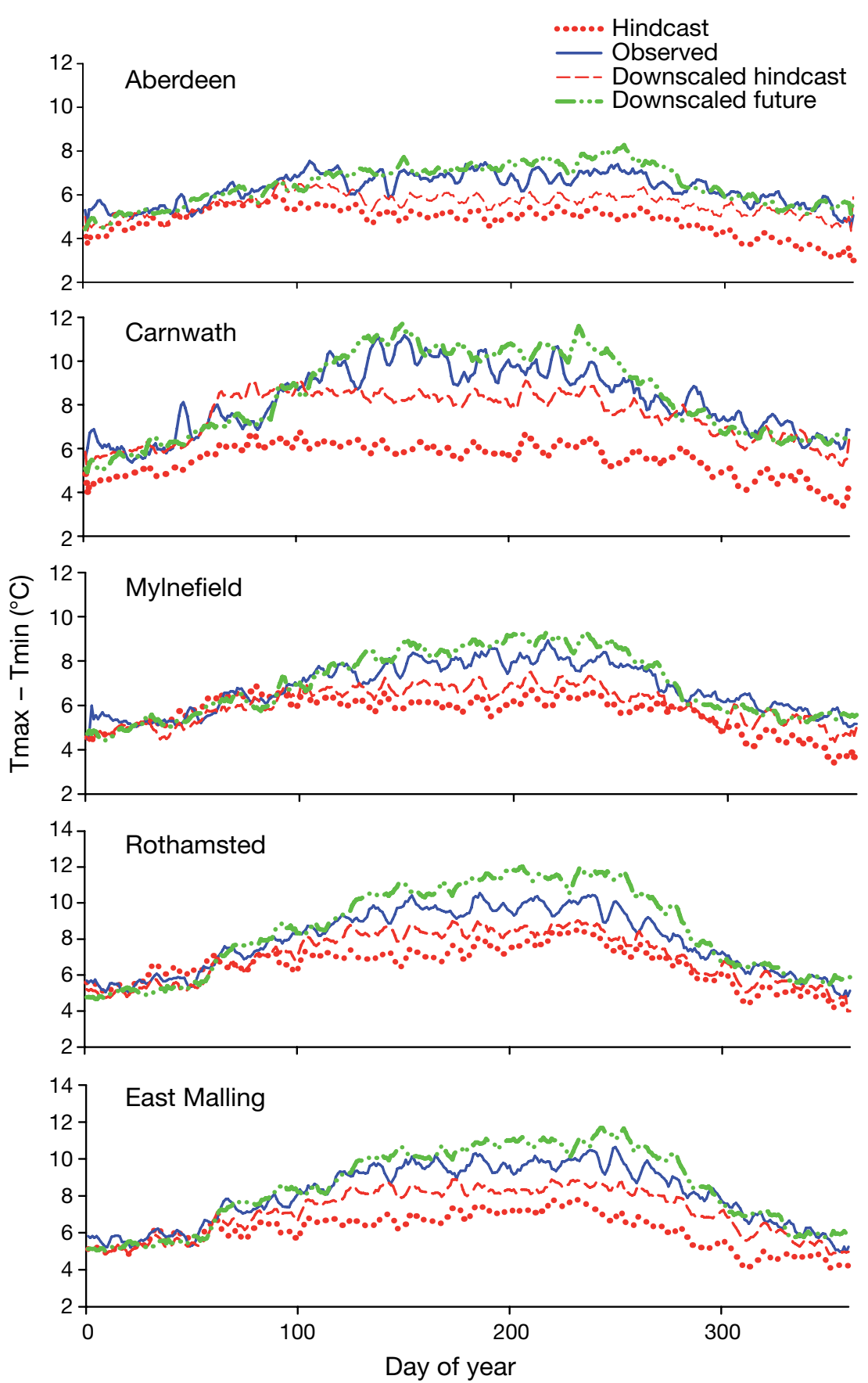

Fig. 7. Tmax - Tmin comparisons for HadRM3 hindcast, observed data, downscaled HadRm3 hindcast (1960-1990) and downscaled HadRM3 A2 scenario projection (2070-2100) at 5 selected sites

4.2.3. Solar radiation. $\mathrm{DF}_{\mathrm{SR}}$ greatly improved the quality of estimates (Figs. 5B \& 9), but while not eliminating the errors, resulted in them being evenly distributed about a more realistic mean value. In crop modelling, for example, getting the mean value correct is more important than tracking the day-to-day changes, as compensating errors can result in a bal- ance about the mean. $\mathrm{DF}_{\mathrm{SR}}$ does, however, reduce the seasonal bias seen in the hindcast estimates (underestimating in late spring to early summer, i.e. Everton and Sutton Bonington, Fig. 9), giving a more even temporal distribution of overand underestimations. The magnitude of the errors, approximately $4 \mathrm{MJ} \mathrm{m}^{2} \mathrm{~d}^{-1}$, is comparable with those associated with specialised solar radiation estimation models. Therefore, the downscaled estimates for SR can be seen as being of good quality.

\subsection{Downscaled future estimates}

The differences between observed conditions and future projections can be better evaluated given knowledge of the performance of the model in making the hindcast estimates (i.e. identifying systematic errors), and interpreting the impacts (improvements and continuing inadequacies) of using the DFs.

4.3.1. Precipitation. Downscaled future projections for the A2 scenario show a substantial increase in the number of dry days (mean of $23 \mathrm{~d}$ ) at all locations, but a varied response in the change in MAT (Table 1). In 6 cells the annual total is projected to rise, in 4 there is little change, but in 7 a decrease is projected. The decreases are predominantly in drier locations. Fig. 2 indicates that where decreases in MAT are projected, this would be due to a reduction in the number of lower magnitude $(<4 \mathrm{~mm})$ precipitation events.

4.3.2. Temperature. Downscaled estimates indicate a substantial warming at all locations tested (Figs. 10 \& 11) where mean annual Tmax for all sites rises by $3.52^{\circ} \mathrm{C}$, from the observed 12.28 to a projected $15.80^{\circ} \mathrm{C}$ (Table 2). For Tmin, the mean annual value rises by $3.22^{\circ} \mathrm{C}$, from 5.14 to $8.36^{\circ} \mathrm{C}$, for all sites. Projections for Tmin approach what is approximately the current difference between observed Tmax - Tmin (Fig. 11). However, the evidence presented here shows the model overestimates the higher ranges of Tmax and Tmin in the summer period by an average of $3^{\circ} \mathrm{C}$ 
Table 2. Mean annual observed and HadRM3 hindcast (1960-1990) maximum and minimum temperature (Tmax and Tmin, $\left.{ }^{\circ} \mathrm{C}\right)$ before and after application of downscaling factors and downscaled HadRM3 A2 scenario projections (2070-2100). Obs: observed; Model: HadRM3 hindcast; Diff: difference (before downscaling - observed)

\begin{tabular}{|c|c|c|c|c|c|c|c|c|c|c|c|}
\hline \multirow[t]{3}{*}{ Stn } & \multirow[t]{3}{*}{ Cell } & \multirow{3}{*}{ Obs } & \multirow{2}{*}{\multicolumn{3}{|c|}{$\begin{array}{c}\text { - Mean annual Tmax }\left({ }^{\circ} \mathrm{C}\right) \\
\text { Model }\end{array}$}} & \multirow{3}{*}{$\begin{array}{c}\text { Downscaled } \\
\text { Projection }\end{array}$} & \multirow{3}{*}{ Obs } & \multirow{2}{*}{\multicolumn{3}{|c|}{$\begin{array}{l}\text { - Mean annual Tmin }\left({ }^{\circ} \mathrm{C}\right) \\
\text { Model }\end{array}$}} & \multirow{3}{*}{$\begin{array}{c}\text { Downscaled } \\
\text { Projection }\end{array}$} \\
\hline & & & & & & & & & & & \\
\hline & & & Before & After & Diff & & & Before & After & Diff & \\
\hline Aberdeen & 4273 & 11.12 & 10.46 & 11.12 & -0.66 & 14.07 & 4.83 & 4.95 & 4.83 & 0.12 & 7.60 \\
\hline Aberporth & 5434 & 12.16 & 12.12 & 12.16 & -0.05 & 14.57 & 6.92 & 10.31 & 6.92 & 3.39 & 9.41 \\
\hline Aldergrove & 4797 & 12.38 & 11.70 & 12.38 & -0.68 & 15.17 & 5.57 & 5.75 & 5.57 & 0.18 & 8.17 \\
\hline Auchincruive & 4693 & 11.99 & 11.22 & 11.99 & -0.77 & 16.93 & 5.55 & 4.66 & 5.55 & -0.90 & 9.57 \\
\hline Auchincruive & 4694 & 11.99 & 10.52 & 11.99 & -1.47 & 15.00 & 5.55 & 4.57 & 5.55 & -0.99 & 8.47 \\
\hline Bracknell & 5757 & 13.88 & 13.55 & 13.88 & -0.33 & 18.28 & 5.44 & 6.19 & 5.44 & 0.75 & 9.12 \\
\hline Carnwath & 4589 & 11.12 & 11.19 & 11.12 & 0.07 & 14.31 & 2.87 & 4.95 & 2.87 & 2.08 & 5.85 \\
\hline Cawood & 5121 & 13.01 & 12.42 & 13.01 & -0.58 & 16.52 & 5.21 & 5.34 & 5.21 & 0.13 & 8.90 \\
\hline East Malling & 5759 & 14.09 & 13.99 & 14.09 & -0.09 & 18.28 & 6.05 & 6.97 & 6.05 & 0.92 & 9.79 \\
\hline Eskdalemuir & 4695 & 10.79 & 10.46 & 10.79 & -0.34 & 13.98 & 3.38 & 4.52 & 3.38 & 1.14 & 6.30 \\
\hline Eskdalemuir & 4801 & 10.79 & 11.53 & 10.79 & 0.74 & 14.08 & 3.38 & 4.40 & 3.38 & 1.02 & 6.66 \\
\hline Everton & 5862 & 13.81 & 13.72 & 13.81 & -0.09 & 18.10 & 6.81 & 5.80 & 6.81 & -1.01 & 10.76 \\
\hline Lerwick & 3639 & 9.22 & 9.49 & 9.22 & 0.27 & 11.13 & 4.71 & 8.28 & 4.71 & 3.56 & 6.68 \\
\hline Mylnefield & 4484 & 11.84 & 11.41 & 11.84 & -0.43 & 15.05 & 5.03 & 5.01 & 5.03 & -0.02 & 8.05 \\
\hline Rothamsted & 5652 & 13.21 & 13.66 & 13.21 & 0.45 & 17.50 & 5.32 & 6.21 & 5.32 & 0.89 & 8.97 \\
\hline Sutton Bonnington & 5333 & 13.32 & 12.65 & 13.32 & -0.67 & 17.31 & 5.48 & 5.59 & 5.48 & 0.11 & 8.85 \\
\hline Wallingford & 5650 & 14.03 & 13.53 & 14.03 & -0.50 & 18.33 & 5.28 & 6.11 & 5.28 & 0.82 & 8.89 \\
\hline Mean & & 12.28 & 11.98 & 12.28 & -0.30 & 15.80 & 5.14 & 5.86 & 5.14 & 0.72 & 8.36 \\
\hline \multicolumn{2}{|l|}{ Absolute difference } & & & & 5.13 & & & & & 12.22 & \\
\hline \multicolumn{2}{|c|}{ Mean absolute difference } & & & & 0.48 & & & & & 1.06 & \\
\hline
\end{tabular}

Table 3. Comparison between observed and HadRM3 hindcast (1960-1990) Tmax $\left({ }^{\circ} \mathrm{C}\right)$ for highest and lowest single value, and the no. of $\mathrm{d}>15^{\circ} \mathrm{C}$ before and after application of DF, and downscaled HadRM3 A2 scenario projection (2070-2100). Obs: observed; Model: HadRM3 hindcast

\begin{tabular}{|c|c|c|c|c|c|c|c|c|c|c|c|c|c|}
\hline \multirow[t]{3}{*}{ Stn } & \multirow[t]{3}{*}{ Cell } & \multicolumn{4}{|c|}{ Tmax highest single value $\left({ }^{\circ} \mathrm{C}\right)$} & \multicolumn{4}{|c|}{ Tmax lowest single value $\left({ }^{\circ} \mathrm{C}\right)$} & \multicolumn{4}{|c|}{ Mean $\mathrm{d}>15^{\circ} \mathrm{C}(\mathrm{n})$} \\
\hline & & \multirow[t]{2}{*}{ Obs } & \multicolumn{2}{|c|}{ Model } & \multirow{2}{*}{$\begin{array}{c}\text { Downscaled } \\
\text { Projection }\end{array}$} & \multirow[t]{2}{*}{ Obs } & \multicolumn{2}{|c|}{ Model } & \multirow{2}{*}{$\begin{array}{l}\text { Downscaled } \\
\text { Projection }\end{array}$} & \multirow[t]{2}{*}{ Obs } & \multicolumn{2}{|c|}{ Model } & \multirow{2}{*}{$\begin{array}{l}\text { Downscaled } \\
\text { Projection }\end{array}$} \\
\hline & & & Before & After & & & Before & After & & & Before & After & \\
\hline Aberdeen & 4273 & 26.4 & 33.7 & 34.3 & 36.6 & -3.4 & -5.6 & -5.3 & 1.3 & 86 & 70 & 72 & 155 \\
\hline Aberporth & 5434 & 31.5 & 22.7 & 24.1 & 27.4 & -5.2 & 1.1 & -0.4 & 3.2 & 106 & 82 & 97 & 170 \\
\hline Aldergrove & 4797 & 24.9 & 23.9 & 33.3 & 38.8 & 0.5 & 1.3 & -2.1 & 1.2 & 121 & 93 & 123 & 180 \\
\hline Auchincruive & 4693 & 29.4 & 32.1 & 32.8 & 46.8 & -3.2 & -8.4 & -6.9 & 1.8 & 107 & 88 & 105 & 202 \\
\hline Auchincruive & 4694 & 29.4 & 31.5 & 32.7 & 39.1 & -3.2 & -6.5 & -5.7 & 0.6 & 107 & 72 & 110 & 176 \\
\hline Bracknell & 5757 & 35.3 & 40.2 & 40.6 & 47.1 & -7.0 & -5.5 & -4.8 & 0.8 & 156 & 138 & 153 & 213 \\
\hline Carnwath & 4589 & 29.7 & 35.5 & 35.5 & 41.5 & -11.7 & -2.9 & -4.3 & -0.2 & 96 & 94 & 101 & 166 \\
\hline Cawood & 5121 & 33.9 & 38.7 & 39.2 & 45.6 & -5.0 & -4.2 & -4.5 & 2.1 & 141 & 121 & 142 & 198 \\
\hline East Malling & 5759 & 34.6 & 41.1 & 40.8 & 47.1 & -5.9 & -5.7 & -5.3 & 2.3 & 160 & 146 & 158 & 219 \\
\hline Eskdalemuir & 4695 & 29.5 & 33.6 & 34.0 & 42.1 & -9.9 & -6.2 & -7.0 & -1.3 & 85 & 76 & 89 & 157 \\
\hline Eskdalemuir & 4801 & 29.5 & 35.1 & 34.1 & 42.3 & -9.9 & -5.8 & -5.6 & -1.5 & 85 & 104 & 86 & 157 \\
\hline Everton & 5862 & 33.5 & 39.5 & 38.0 & 47.2 & -4.8 & -7.3 & -7.7 & 0.5 & 151 & 141 & 151 & 219 \\
\hline Lerwick & 3639 & 21.5 & 16.0 & 17.3 & 20.1 & -3.4 & -1.3 & -3.1 & 1.4 & 17 & 1 & 8 & 54 \\
\hline Mylnefield & 4484 & 28.5 & 36.3 & 36.5 & 40.6 & -9.0 & -3.1 & -3.3 & 0.4 & 112 & 101 & 112 & 176 \\
\hline Rothamsted & 5652 & 33.8 & 40.6 & 40.0 & 46.5 & -7.2 & -5.6 & -5.7 & 0.5 & 145 & 141 & 142 & 204 \\
\hline Sutton Bonington & 5333 & 34.8 & 40.0 & 40.9 & 47.7 & -6.7 & -5.1 & -4.1 & 1.1 & 144 & 125 & 145 & 206 \\
\hline Wallingford & 5650 & 35.1 & 40.8 & 41.5 & 47.3 & -9.2 & -4.9 & -4.2 & 0.6 & 158 & 137 & 156 & 215 \\
\hline Mean & & 30.7 & 34.2 & 35.0 & 41.4 & -6.1 & -4.4 & -4.7 & 0.9 & 116 & 102 & 115 & 180 \\
\hline
\end{tabular}



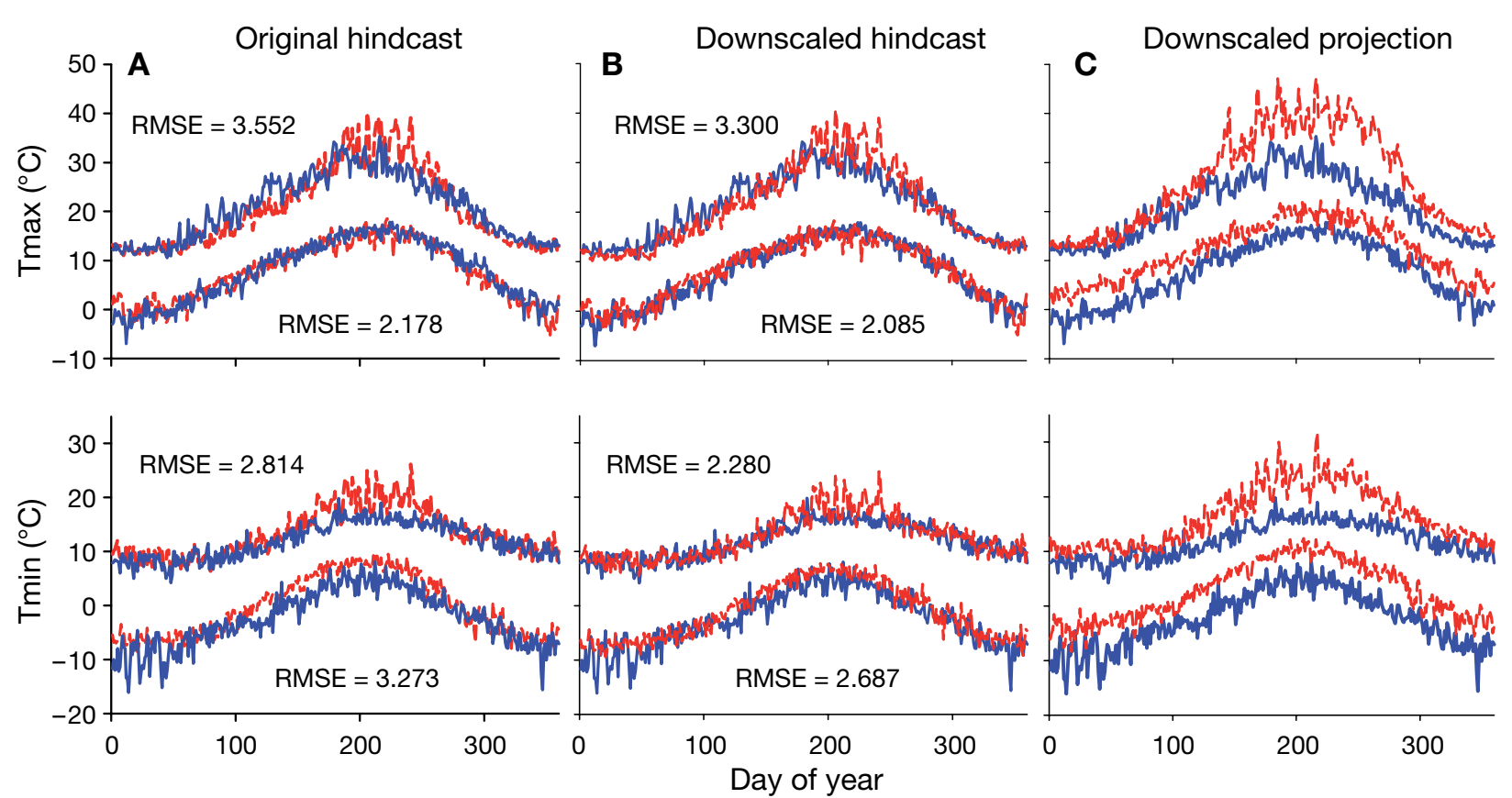

Fig. 8. Comparison of observed data (blue) and (A) HadRM3 hindcast, (B) downscaled HadRM3 hindcast (1960-1990) and (C) downscaled HadRM3 A2 scenario projection (2070-2100) estimates (red) of the highest and lowest values (upper and lower set of red and blue lines, respectively) of Tmax and Tmin for Bracknell. RMSE: root mean square error $\left({ }^{\circ} \mathrm{C}\right)$

across all sites before downscaling, and $4^{\circ} \mathrm{C}$ afterwards (Fig. 8B). Hence the values for the highest single values of Tmax and Tmin given in Tables $3 \& 4$ and shown in Fig. $8 \mathrm{C}$ should be regarded with caution. The increase in both Tmax and Tmin appears to be similar, given the downscaled Tmax - Tmin (Fig. 7), and considering that the mean daily Tmax estimates (Fig. 11) may be too high due to distortion arising from the model's overestimation of the higher Tmax values. Allowing for this, the downscaled Tmax does increase more than Tmin in the summer. The projected data show a substantial increase in the number of days on which $\operatorname{Tmax}<15^{\circ} \mathrm{C}$ (observed $=116 \mathrm{~d}$, downscaled hindcast $=115$, projection $=180)($ Table 3$)$.

The model is unable to represent the more extreme cold conditions at some locations, hence the projected values given for the lowest Tmin in Table 4 are also questionable. That said, the application of the DF does improve the quality of estimates in terms of the no. $\mathrm{d}<0^{\circ} \mathrm{C}$ and $<-5^{\circ} \mathrm{C}$. Therefore greater confidence can be found in the projected number of days below these values, showing there is a substantial decrease in the expected number of cold days.

4.3.3. Solar radiation. Change may occur to $S R$ only in spring to early autumn (May to September), as there is little difference from the observed data outside this period (Figs. 12 \& 13). Aberdeen, Aberporth and Aldergrove show very little change in SR, at whilst Lerwick may decrease from mid-summer into winter. Sites in the southern UK show the greatest increase in
SR in the summer (i.e. Everton, Rothamsted, Wallingford). The application of $\mathrm{DF}_{\mathrm{SR}}$ produces a characteristic 'spike and dip' in the plots of mean daily SR (Fig. 13) between Days 149 and 151 (the transition from May to June). This is due to the model estimating the May SR well, giving small values for May $\mathrm{DF}_{\mathrm{SR}}$, but overestimating the June SR giving a higher June $\mathrm{DF}_{\mathrm{SR}}$, which is compounded by the smoothing method used to display the results in Fig. 13.

\section{DISCUSSION}

\subsection{Model evaluation}

The evaluation of the quality of estimates for the period 1960-1990 has implications for the interpretation of future projections of CC. Assuming that the systematic differences between modelled and observed data occurring within the hindcast estimates are present in the future estimates, then future unadjusted projections, as currently published, of precipitation, extreme summer Tmax, mean Tmin, lowest Tmin and SR are, at some locations, potentially misleading. However, testing also indicated that mean Tmax, the lowest Tmax and highest Tmin estimates are reliable, requiring minimal downscaling. On balance, there is therefore a need for more comparisons between RCM estimates and observed data, to systematically identify cases where the model performs poorly with the aim of 

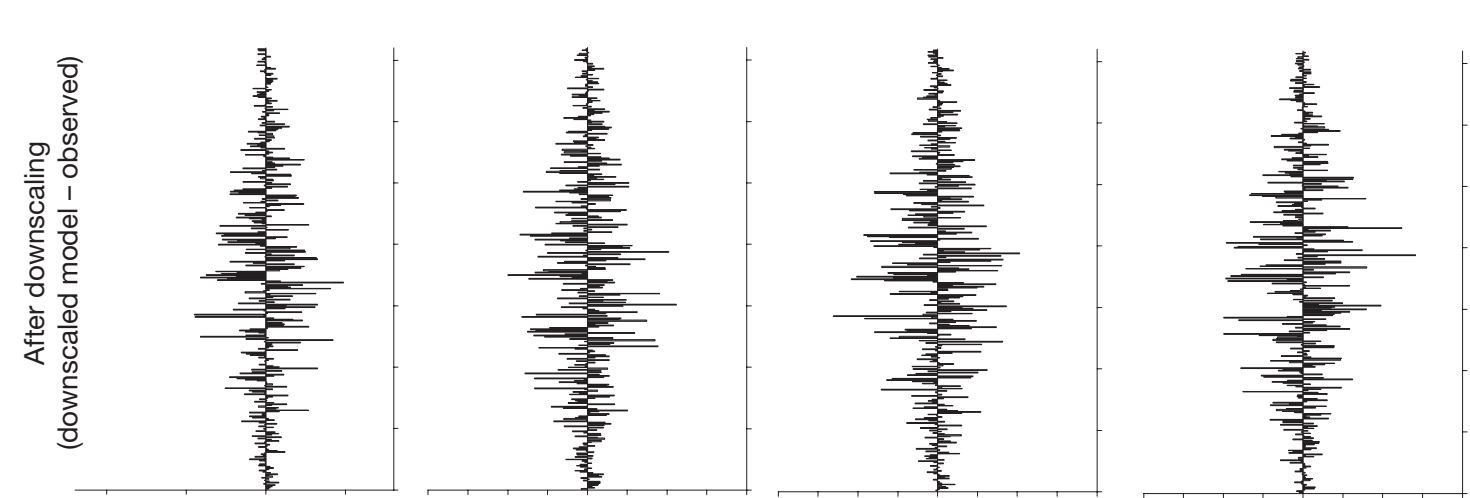

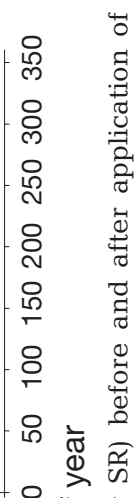
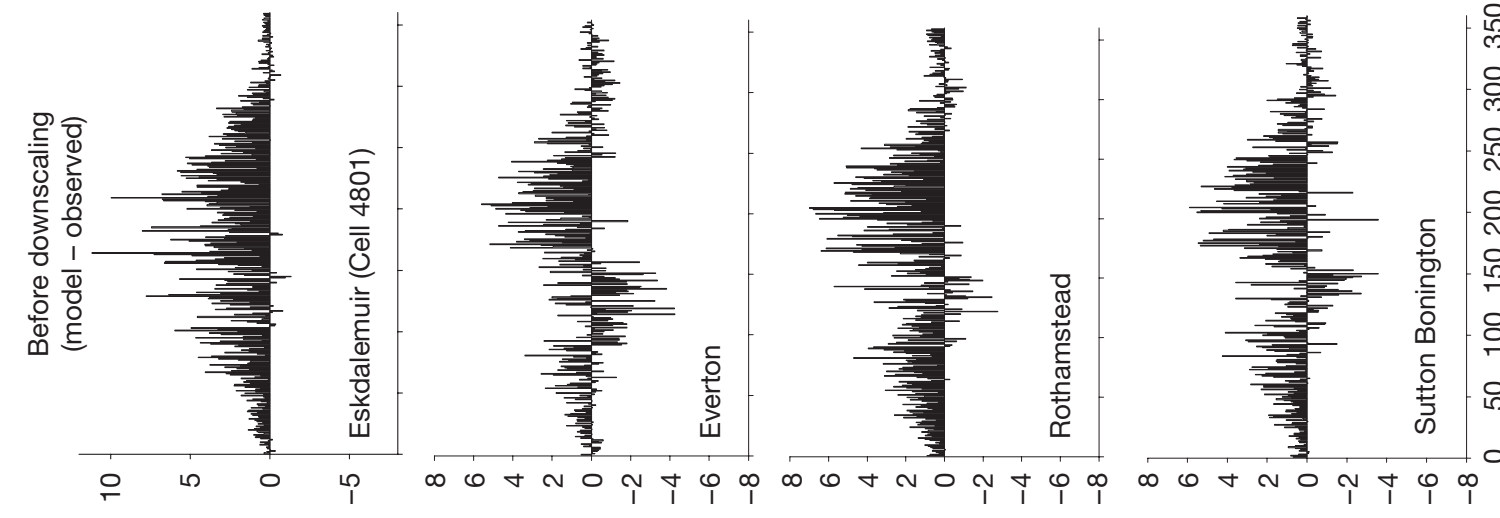

융 त 중

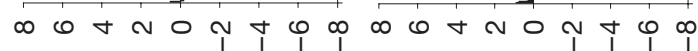

0
8
0
0

도월
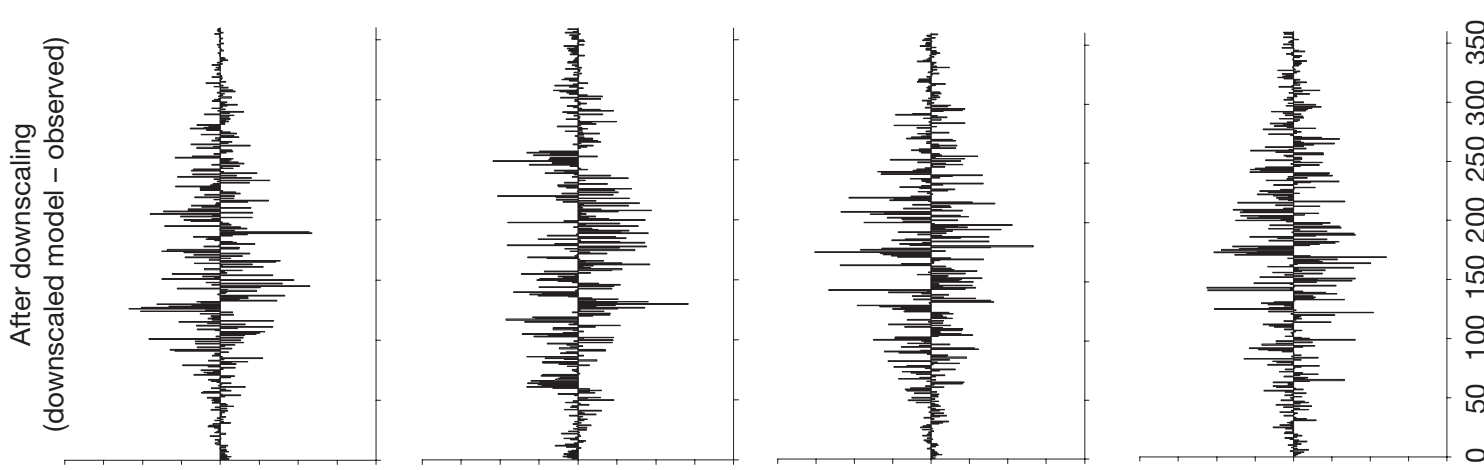

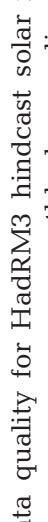
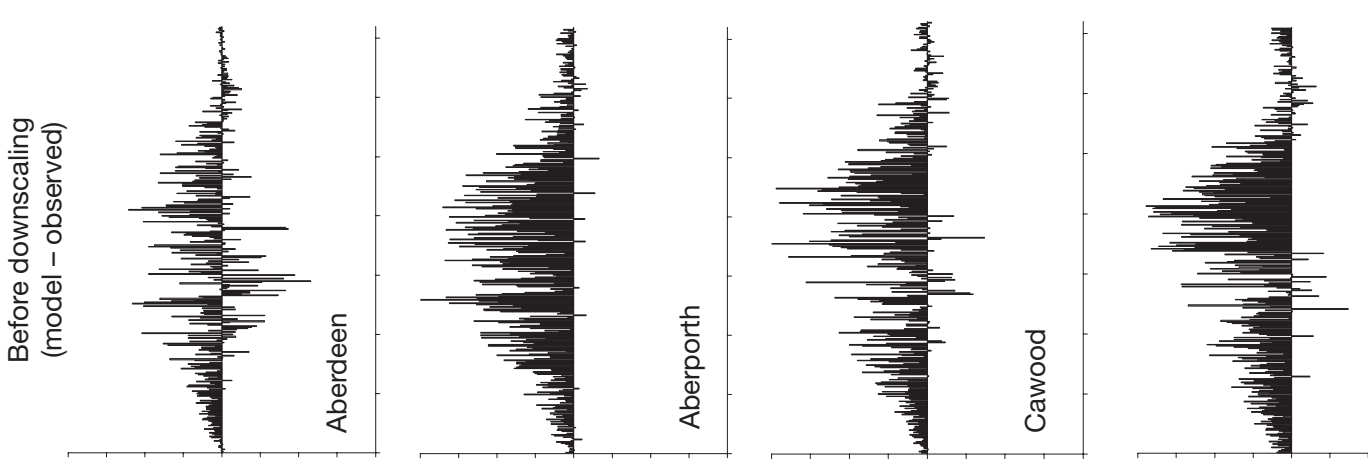

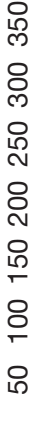

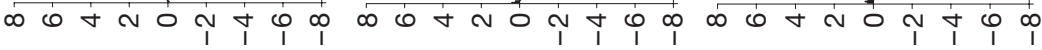

Difference in mean daily SR (modelled-observed) ( $\left.\mathrm{MJ} \mathrm{m}^{-2} \mathrm{~d}^{-1}\right)$ 


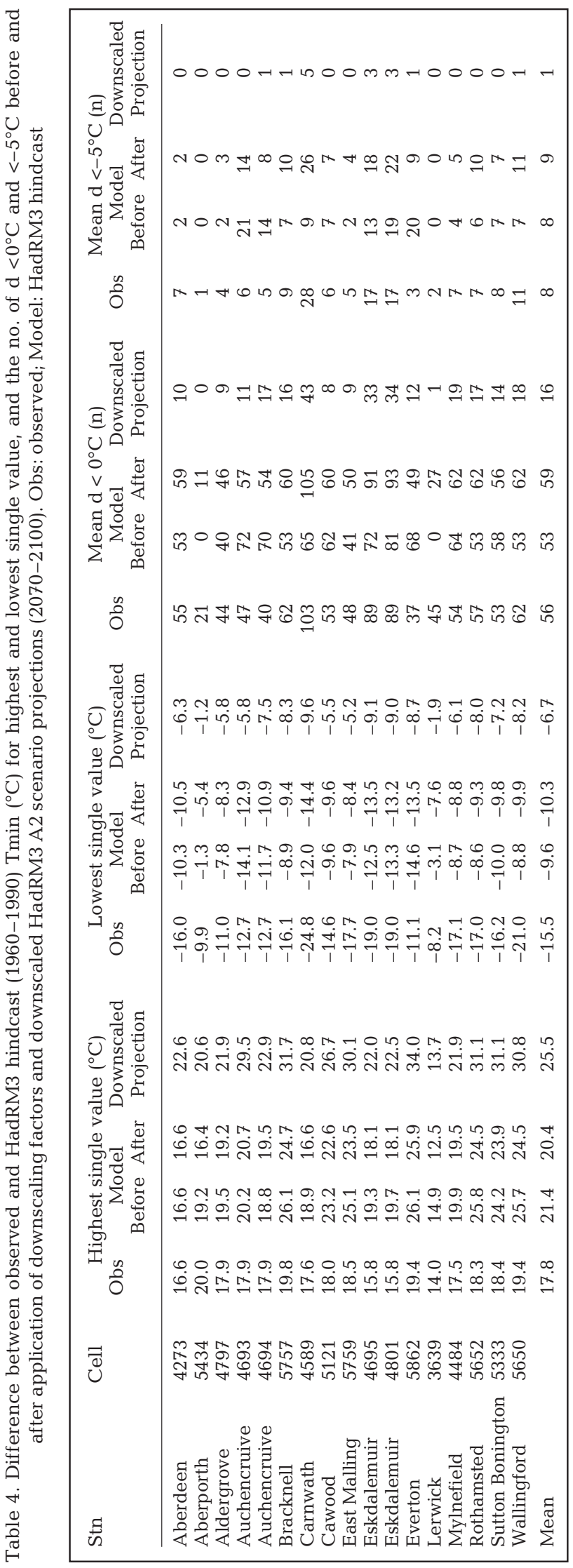

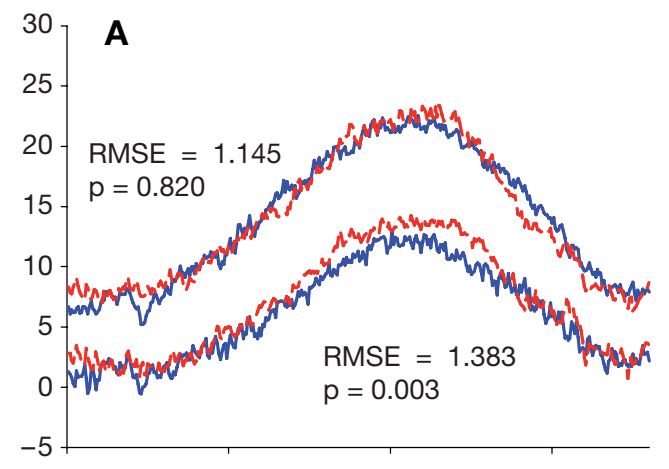
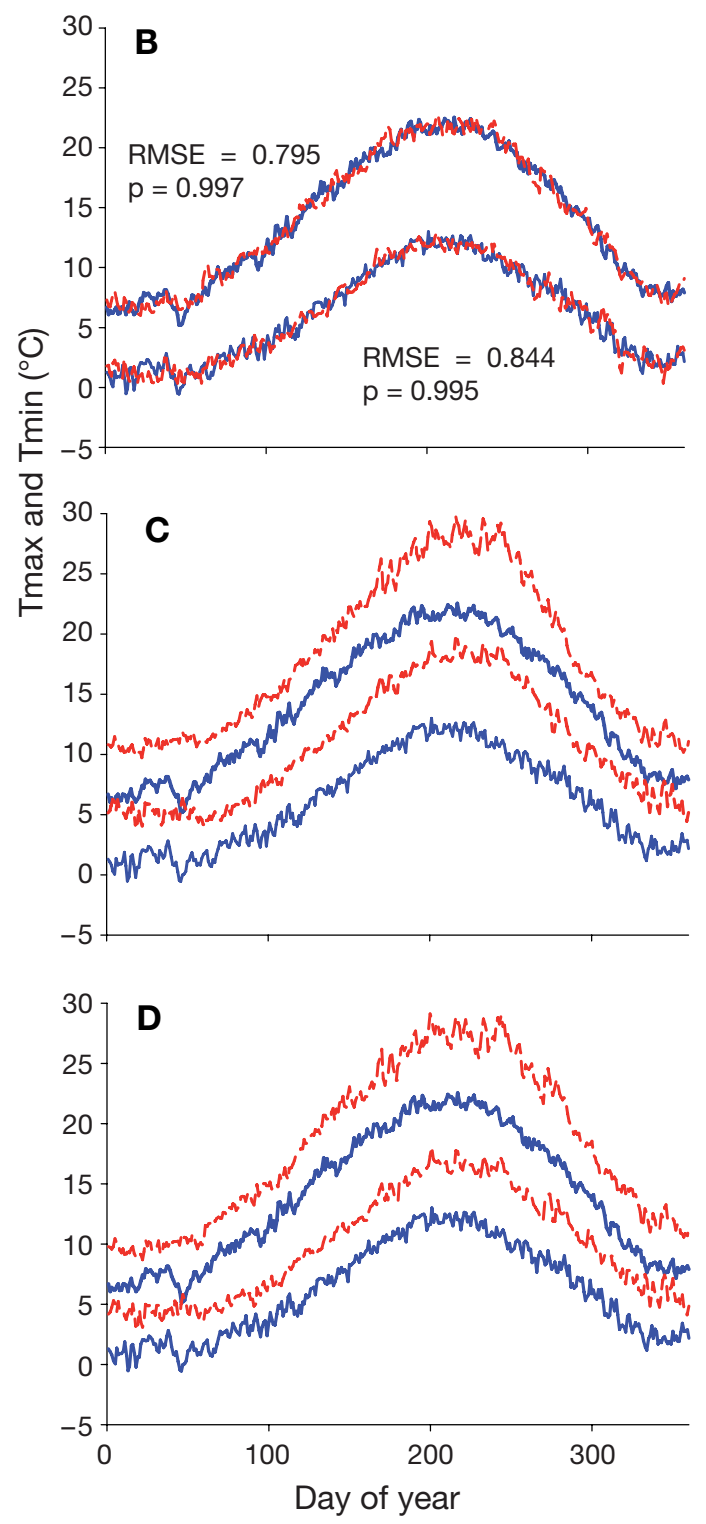

Fig. 10. Comparison of mean daily Tmax and Tmin observed data (blue) with (A) HadRM3 hindcast, (B) downscaled HadRM3 hindcast (1960-1990), (C) HadRM3 A2 scenario projection and (D) downscaled HadRM3 A2 scenario projection (2070-2100) estimates (red) for East Malling. RMSE: root mean square error $\left({ }^{\circ} \mathrm{C}\right)$; p: 2-tailed paired $t$-test probability of means being equal (where 1 is very high probability) 


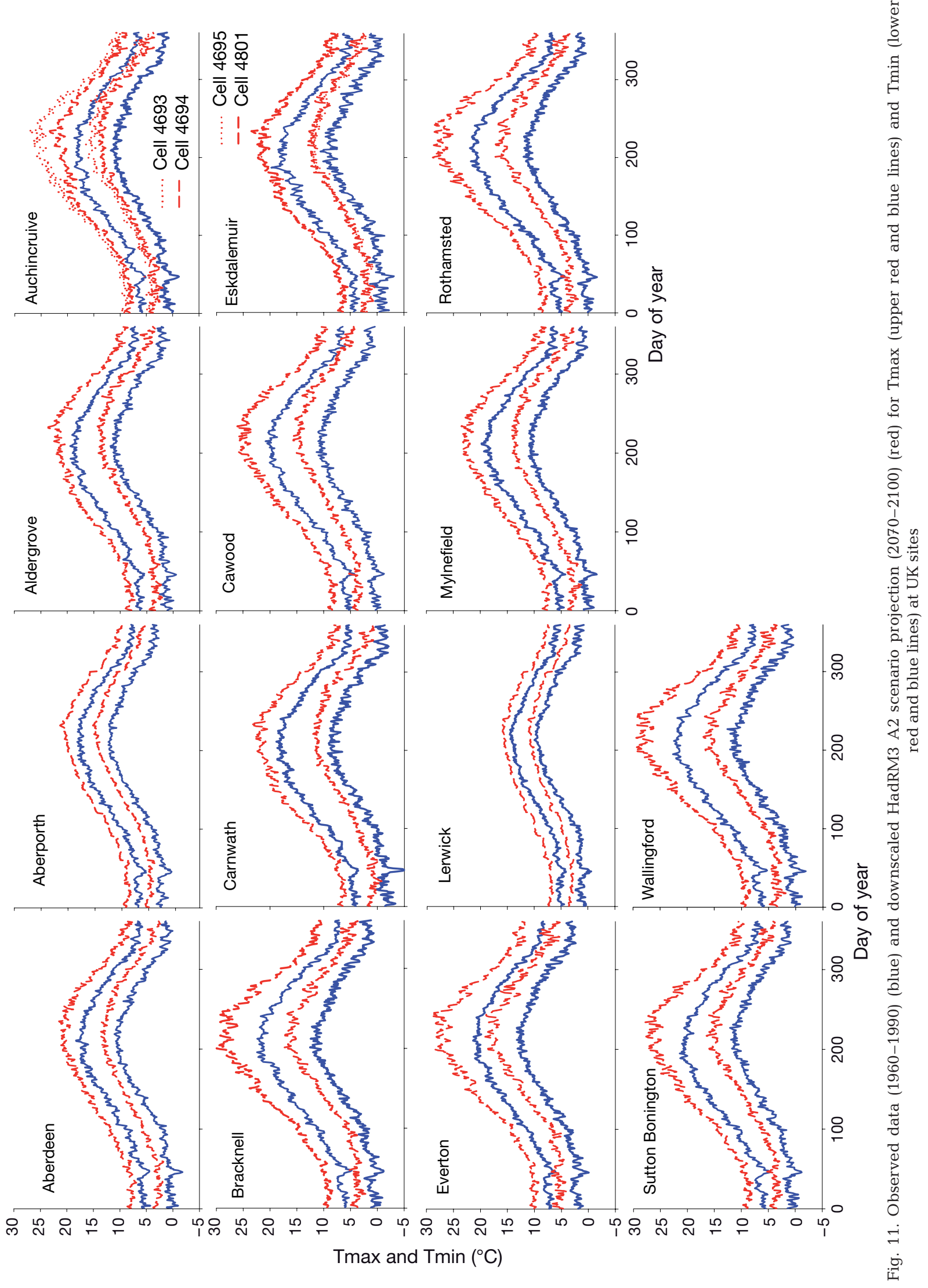




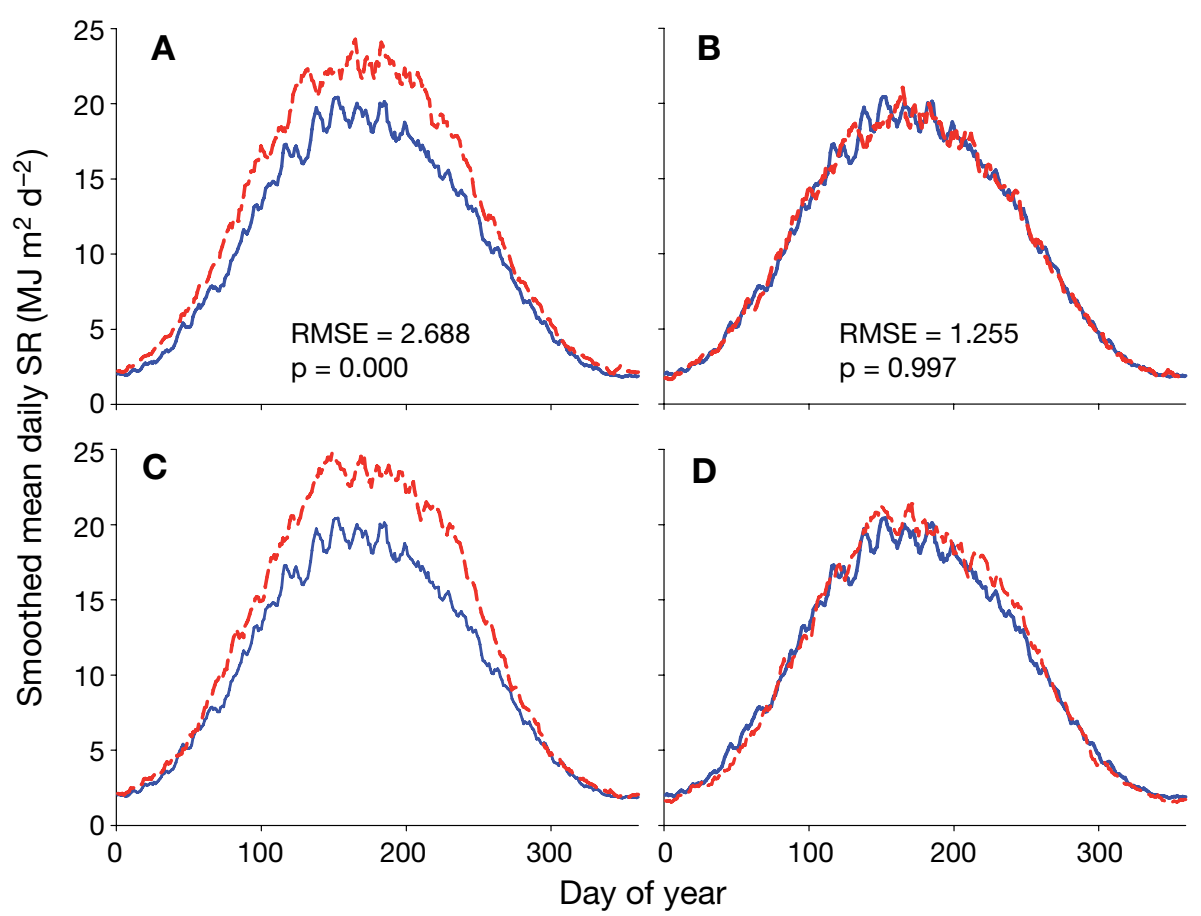

Fig. 12. Comparison of smoothed observed (blue) and modelled (red) solar radiation (SR) for (A) HadRM3 hindcast, (B) downscaled HadRM3 hindcast (1960-1990), (C) HadRM3 A2 scenario projection and (D) downscaled HadRM3 A2 scenario projection (2070-2100) for Aberporth. RMSE: root mean square error $\left({ }^{\circ} \mathrm{C}\right)$; $\mathrm{p}$ : 2-tailed paired $t$-test probability of means being equal (where 1 is very high probability), derived from unsmoothed data

apportioning the cause of differences to model structure (within the RCM), process representation (the difference between the $50 \mathrm{~km}$ cell and the site attributes), RCM input data or parameterisation.

The many modelled small precipitation events $(<0.3 \mathrm{~mm})$, without downscaling, may be significant in terms of adversely affecting derived estimates, i.e. evapotranspiration (and therefore soil water balance) and crop canopy temperatures, due to increased cooling. They are, however, less likely to impact on hydrological studies, given the relatively low volume of water input into hydrological systems. These many small events occur due to the model being originally calibrated and validated against spatially aggregated observed data, resulting in a 'drizzle' effect. The fact that the model did not estimate the largest single events does not indicate a failure of the model, but that the $30 \mathrm{yr}$ coverage of the hindcast may not be sufficient to capture the more rare extreme events with longer return periods. In conjunction with this, the aim of the model is to represent the mean conditions for a grid cell, rather than specific extreme events recorded at individual stations. However, the consistency with which the model underestimated the largest single event across all sites does indicate a limitation.

The models' tendency to overestimate Tmin, whilst performing well for Tmax, implies that without down- scaling the data will be unsuitable (dependent on location) for many CC impact and adaptation studies. Errors will be introduced to estimates of an entity's temperature response, i.e. due to thermal time accumulation, diurnal ranges, biophysical processes etc. However, the results presented here for mean daily Tmax and Tmin and their highest and lowest values, indicate that the model is capable-after downscaling - of performing well in producing data that represent the natural temperature variability on a daily basis.

The overestimation of SR at many locations suggests that the model data without downscaling are unsuitable for use in impacts studies where SR is a key input. Even where mean values match the seasonal distribution of differences between observed and modelled data, the timing of errors can be important. For example, if the data are used within a crop model, overestimation of SR in the spring and summer will result in too high a rate of biomass accumulation (more intercepted radiation). The authors' experience is that data containing compensating errors of the type found in the downscaled SR estimates can still result in reasonable derived estimations of modelled yield (Rivington et al. 2002). The overestimation of SR could indicate a weakness in the way the RCM represents cloud cover. 

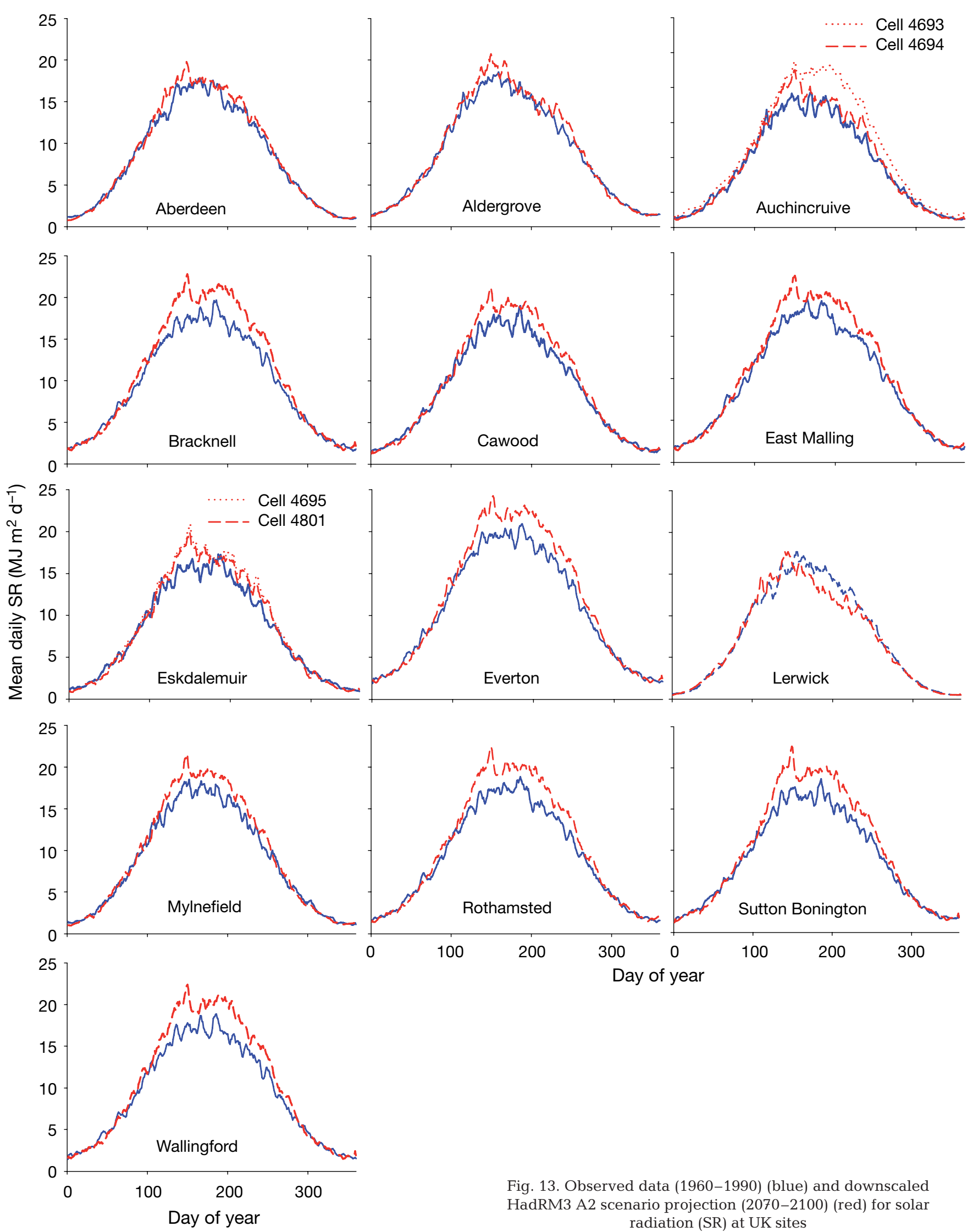

Day of year

Fig. 13. Observed data (1960-1990) (blue) and downscaled HadRM3 A2 scenario projection (2070-2100) (red) for solar radiation (SR) at UK sites 


\subsection{Downscaling factor method}

Given that both over- and underestimation of weather variables can occur at the same location, there is a risk of introducing significant errors for applications where estimates, e.g. of soil water deficit, are derived from several weather variables. The use of DFs greatly improves the quality of hindcast estimates compared with observed data, hence there will be an associated improvement in estimates derived from the variables. However, $\mathrm{DF}_{\mathrm{MAT}}$ does introduce additional errors in the largest precipitation events. This is due to the $\mathrm{DF}_{\mathrm{MAT}}$ being applied proportionally to the magnitude of the event, hence the largest 3 to 4 modelled events can become excessively large. Care would be needed if the data is used in hydrological modelling of flood risk assessment. The trade-off with the $\mathrm{DF}_{\mathrm{d}}$ and $\mathrm{DF}_{\mathrm{MAT}}$ methods is that they do correct well for the vast majority of small to medium sized precipitation events. Also, the temperature DFs, whilst improving the representation of means, do not eradicate model biases for extreme low and high temperatures. Practitioners using any form of downscaling technique need to be aware of how remaining or exacerbated biases, such as those above, will manifest themselves when used in CC impact studies.

Greater confidence can be gained in the future projections of derived estimates (e.g. soil water deficit) after adjustment of the input weather variables by the DFs. However, further development potential exists, to relate the DFs to the future atmospheric physical properties and role of radiative forcing, i.e. relationship with air temperature and cloud formation. The current assumption that the hindcast dry-days bias will persist into the future projections may be misleading, due to changing atmospheric dynamics, hence $\mathrm{DF}_{\mathrm{d}}$ may over-correct.

The methods developed are simple to calibrate and implement, requiring just observed and hindcast data, raising the potential for rapid recalibration of newly generated RCM data for specific sites. These DFs are, however, applied to individual weather variables independently and do not take into account the correlation between variables. The model appears to represent the cross correlation between variables well, and the DFs only strongly affect the mean and variance per variable, hence their impact on cross correlation should be minor. Also, the DFs can be applied separately, e.g. when the model is found to perform well for temperature, but not precipitation or solar radiation.

The ability of the DFs to improve the quality of estimates appears to be spatially and temporally uniform. However, they may be inappropriate for temperature where there are large sea areas within a cell, e.g. Aberporth and Lerwick. Therefore thresholds need to be set on the results of the evaluation of the original model estimates, in order to decide when it is inappropriate to downscale.

\section{CONCLUSIONS}

This research has shown the value of appraising the ability of RCM to replicate the historical climate in order to better evaluate the quality of future projections. The evaluation of the HadRM3 RCM has shown that it produces estimates of the historical climate that will introduce additional uncertainty when used in CC impact and adaptation studies. The model produces an excess of small precipitation events $(<0.3 \mathrm{~mm})$, whilst giving either accurate or large over- and underestimations of MAT, variable with location. Estimate quality is better for Tmax than Tmin, the latter tends to be overestimated by the model. Generally, the lower values of Tmax and higher values of Tmin are estimated well. The model systematically overestimates solar radiation, but does produce good quality estimates at a few sites. The combination of these errors implies that the original estimates are unsuitable for use in detailed CC impact and adaptation studies, e.g. those concerned with daily time steps. However, the hindcast model estimates are sufficiently similar to observed data in many cases to raise the potential for downscaling.

Where there are significant differences between observed and RCM hindcast data, this paper has shown that simple, non-statistically based DFs can be applied that result in a considerably closer match between observed and modelled hindcast data. Improvements in data quality are spatially and temporally uniform. With the assumption that the type and approximate magnitude of errors occurring in the hindcast estimates are repeated in the modelled future climate, then the application of DF means that greater confidence can be placed in RCM projections for particular locations that may be of interest to decision makers. Given the simplicity of the downscaling method there is potential for using this approach to adjust newly generated RCM data as it becomes available. This does, however, depend on the archiving and publishing of the hindcast data associated with each RCM scenario, which is not always done currently. There is potential for considerable refinement and further testing of the precipitation and temperature DFs, since there are many more meteorological stations in the UK, and elsewhere, with suitable data available (this study being restricted to those sites with available solar radiation data).

Without the use of a suitable downscaling approach, or until RCMs improve and better represent the historical climate, then site-specific climate impacts and adaptation studies using original RCM data are likely to have significant introduced uncertainty. 
Acknowledgements. We thank the Scottish Executive RERAD for their funding support, and Mr. K. Marsh (BADC) for processing the HadRM3 model data; and the Meteorological Office and Hadley Centre for permission to use their data.

\section{LITERATURE CITED}

Achberger C, Linderson ML, Chen D (2003) Performance of the Rossby Centre regional atmospheric model in Southern Sweden: comparison of simulated and observed precipitation. Theor Appl Climatol 76:219-234

Antic S, Laprise R, Denis B, de Elia R (2006) Testing the downscaling ability of a one-way nested regional climate model in regions of complex topography. Clim Dyn 26:305-325

Bell JL, Sloan LC, Snyder MA (2004) Regional changes in extreme climatic events: a future climate scenario. J Clim 17:81-87

Droogers P, Aerts J (2005) Adaptation strategies to climate change and climate variability: a comparative study between seven contrasting river basins. Phys Chem Earth 30: 339-346

Fowler HJ, Ekstrom M, Kilsby CG, Jones PD (2005) New estimates of future changes in extreme rainfall across the UK using regional climate model integrations. I. Assessment of control climate. J Hydrol 300:212-233

Hay LE, Clark MP, Wilby RL, Gutowski WJ Jr and others (2002) Use of regional climate model output for hydrologic simulations. J Hydrometeorol 3:571-590

Ines AVM, Hansen JW (2006) Bias correction of daily GCM rainfall for crop simulation studies. Agric For Meteorol 138:44-53

IPCC (Inter-Governmental Panel on Climate Change) (2000) Special report on emissions scenarios. Cambridge University Press, Cambridge

Jenkins G, Lowe J (2003) Handling uncertainties in the UKCIP02 scenarios of climate change. Hadley Centre Technical Note 44, 20th November 2003. Meteorological Office, Exeter

Kim J, Lee JU (2003) A multi-year regional climate hindcast for the Western United States using the Mesoscale Atmospheric Simulation Model. J Hydrometeorol 4:878-890

Kleinn J, Frei C, Gurtz J, Luthi D, Vidale PL, Schar C (2005) Hydrologic simulations in the Rhine basin driven by a regional climate model. J Geophys Res 110:D04102

LADSS (2005) Land allocation decision support system: reference manual. Available at: www.macaulay.ac.uk/LADSS/ reference.shtml

LADSS (2006) Land allocation decision support system: HadRM3 data plots. Available at: www.macaulay.ac.uk/ LADSS/hadley_climate_data.html

Maurer EP, Duffy PB (2005) Uncertainty in projections of streamflow changes due to climate change in California. Geophys Res Lett 32:L03704

Moberg A, Jones PD (2004) Regional climate model simula-

Editorial responsibility: Eric DeWeaver,

Madison, Wisconsin, USA tions of daily maximum and minimum near-surface temperatures across Europe compared with observed station data 1961-1990. Clim Dyn 23:695-715

Moriondo M, Bindi M (2006) Comparison of temperatures simulated by GCMs, RCMs and statistical downscaling: potential applications in studies of future crop development. Clim Res 30:149-160

Murphy JM, Sexton DMH, Barnett DM, Jones GS, Webb MJ, Collins M, Stainforth DA (2004) Quantification of modelling uncertainties in a large ensemble of climate change simulations. Nature 430:768-772

Nonhebel S (1994a) The effects of use of average instead of daily weather data in crop growth simulation models. Agric Syst 44:377-396

Nonhebel S (1994b) Inaccuracies in weather data and their effects on crop growth simulation results. I. Potential production. Clim Res 4:47-60

Peng PT, Kumar A, van den Dool H, Barnston AG (2002) An analysis of multimodel ensemble predictions for seasonal climate anomalies. J Geophys Res 107:D04710

Rivington M, Matthews KB, Buchan K (2002) A comparison of methods for providing solar radiation data to crop models and decision support systems. In: Integrated assessment and decision support Proc 1st biennial meeting of the Int Environmental Modelling and Software Society, 24-27 June, Lugano, Vol 3, 193-198

Rivington M, Bellocchi G, Matthews KB, Buchan K (2005) Evaluation of 3 model estimates of solar radiation at 24 UK stations. Agric For Meteorol 132:228-243

Rivington M, Matthews KB, Bellocchi G, Buchan K (2006) Evaluating uncertainty introduced to process-based simulation model estimates by alternative sources of meteorological data. Agric Syst 88:451-471

Rivington M, Matthews KB, Bellocchi G, Buchan K, Stöckle CO, Donatelli M (2007) An integrated assessment approach to conduct analyses of climate change impacts on whole-farm systems. Environ Model Softw 22:202-210

Soulsby C (1995) Contrasts in storm event hydrochemistry in an acidic afforested catchment in upland Wales. J Hydrol 170:159-179

Weibull W (1961) Fatigue testing and analysis of results. Pergamon Press, Oxford

- Widmann M, Bretherton CS, Salathé EP (2003) Statistical precipitation downscaling over the Northwest United States using numerically simulated precipitation as a predictor. J Clim 16:799-816

Wilby RL, Dawson CW, Barrow CM (2002) SDSM - a decision support tool for the assessment of regional climate change impacts. Environ Model Softw 17:147-159

Wood AW, Leung LR, Sridhar V, Lettenmaier DP (2004) Hydrologic implications of dynamical and statistical approaches to downscaling climate model outputs. Clim Change 62:189-216

Zhang XC (2005) Spatial downscaling of global climate model output for site-specific assessment of crop production and soil erosion. Agric For Meteorol 135:215-229

Submitted: November 13, 2006; Accepted: September 3, 2007 Proofs received from author(s): January 31, 2008 